\title{
ARBITRATOR LIABILITY: RECONCILING ARBITRATION AND MANDATORY RULES
}

\author{
ANDREW T. GUZMAN†
}

\begin{abstract}
In this Article, Professor Guzman resolves the tension that exists between mandatory legal rules and the widespread use of arbitration. In recent years, U.S. courts have expanded the range of enforceable arbitration agreements to include agreements that cover areas of law previously thought to be within the exclusive domain of courts. Among the disputes that are now deemed arbitrable are those that implicate mandatory rules such as securities and antitrust laws. Under current law, the willingness of courts to enforce arbitration agreements and to uphold the resulting arbitral awards with minimal judicial review makes it possible for the parties to a transaction to avoid mandatory rules of law. Until now, it has generally been believed that the legal system must either restrict the use of arbitration or permit arbitration and accept that doing so turns all mandatory rules into default rules.
\end{abstract}

This Article proposes a mechanism that permits the continued use of arbitration without abandoning the mandatory nature of legal rules. The recommended approach, called "arbitrator liability," allows the losing party in an arbitration to sue the arbitrator on the ground that a mandatory rule was ignored. Under existing legal rules, arbitrators have an incentive to ignore mandatory rules of law in favor of the contractual terms agreed to by the parties. Arbitrator liability gives arbitrators an incentive to apply mandatory rules of law. Giving proper incentives to arbitrators will ensure that mandatory

$\doteqdot$ Boalt Hall School of Law, University of California at Berkeley. I owe thanks to Richard Brooks, Richard Buxbaum, David Caron, Stephen Choi, Robert Cooter, Jesse Fried, Stephen Ware, David Wilkins, and John Yoo, as well as participants at both the 1999 Friedmann Conference on International Securities Regulation and Antitrust and the Latin American Law and Economics Association 1999 Annual Meetings for helpful comments and discussions. Special thanks to Nicholas Janues and Jeannie Sears. Mehissa Kennedy, Philip Tendler, and Ryan Waterman provided invaluable research assistance. 
rules are enforced, thereby eliminating the incentive for the parties to draft arbitration agreements intended to avoid those rules. The benefits of arbitration can be retained without sacrificing the ability of lawmakers to adopt mandatory rules.

\section{TABLE OF CONTENTS}

Introduction .1281

I. Arbitration and Arbitrability

A. The Problem of Arbitration and Mandatory Rules .......1284

B. The Federal Arbitration Act and the New York Convention .............................................................1288

C. The Expanding Boundaries of Arbitrability .....................1291

1. Arbitration of Claims Under the Securities

Laws 1291

2. Arbitration of Antitrust Claims ................................1295

II. Incentives Under the Status Quo............................................1297

A. The Parties to the Transaction.........................................1298

B. The Arbitrator ....................................................................1301

C. The Impact of Judicial Review ..........................................1307

1. Demanding Evidence That the Arbitrator Will Apply U.S. Law

2. Reviewing Arbitrators' Rulings .....................................1310

III. Reahgning Incentives ...............................................................1316

A. Arbitrator Liability ...........................................................1316

B. Level of Liability ....................................................................1318

C. Repeated Games..................................................................1320

D. Potential Objections to Arbitrator Liability and

Extensions.............................................................1324

1. Excessive Litigation.........................................................1324

2. Risk and Risk-Averse Arbitrators................................1326

3. Relaxing Informational Assumptions ........................1329

4. Verifiability ........................................................................1331

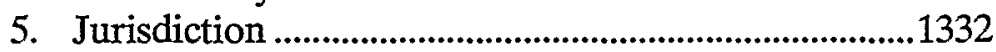

Conclusion 1333 
If [the arbitrator] fails there is practically no remedy available, because most laws do not allow [one] to sue an arbitrator for a wrong decision .....

\section{INTRODUCTION}

The use of arbitration to resolve international business disputes has becoine commonplace. Indeed, most international contracts now contain an arbitration clause, making arbitration, rather than court proceedings, the most common form of dispute resolution for these transactions. ${ }^{2}$ By one account, as inany as $90 \%$ of certain types of large international transactions include arbitration clauses. ${ }^{3}$ Despite the central importance of arbitration, however, it has received scant attention from legal academics. This Article seeks to contribute to the academic hiterature on arbitration by examining the relationship between inandatory legal rules and arbitration. It concludes that existing rules governing judicial review of arbitral decisions are not only inadequate to ensure that inandatory rules are apphied, but they actually encourage arbitrators to ignore such rules. To address this deficiency, the Article proposes the adoption of a regime of "arbitrator hability," under which the parties to an arbitration would have the right to sue the arbitrators if the latter fail to apply mandatory rules. Arbitrator hability reconciles the strong support for arbitration evidenced by U.S. courts and lawmakers with the need to preserve the integrity of inandatory legal rules.

The important role of arbitration is, at least in part, the product of U.S. courts' willingness to enforce arbitration agreements and awards over a wide range of subjects. In the past thirty years, many legal issues that have traditionally been considered "pubhic law" and within the exclusive domain of courts have become arbitrable, greatly expanding the range of issues that can be resolved through arbitration and, therefore, increasing the importance of arbitration. ${ }^{4}$ The ex-

1. Ottoarndt Glossner, Sociological Aspects of International Commercial Arbitration, in THE ART OF ARBITRATION 143, 144 (Jan C. Schultsz \& Albert Jan Van Den Berg eds., 1982).

2. See Pierre Mayer, Mandatory Rules of Law in International Arbitration, 2 ARB. INT'L 274,275 (1986).

3. See Andreas F. Lowenfeld, Can Arbitration Coexist with Judicial Review? A Critique of LaPine v. Kyocera, ADR CURRENTS, Sept. 1998, at 1, 15 n.28 (noting a large New York law firm's experience with international transactions involving investments, joint ventures, technology hicenses, and trade in goods).

4. See infra Part I.C. 
panded role of arbitration, however, has challenged the legal system's efforts to ensure that certain legal rules apply even when parties seek to contract around them. Although much of the legal framework designed to govern business activities consists of default rules, lawmakers have also seen fit to adopt certain mandatory rules-rules imtended to apply to every transaction, regardless of the intent of the parties. Both the securities laws and the antitrust laws, for example, are mandatory. ${ }^{5}$ If, however, the parties to a transaction are permitted to have their disputes resolved through arbitration rather than by a court, it is arbitrators rather than judges who are charged, as an mitial matter, with the application of inandatory rules. The rules will truly be mandatory, therefore, only if arbitrators enforce them even when doing so is contrary to the wishes of the parties, as stated in the arbitration agreement.

This Article demonstrates that arbitrators ${ }^{6}$ are unlikely to enforce mandatory rules when the parties seek to contract around them. The parties to a transaction have great flexibility in the selection of an arbitrator, providing the latter with a strong incentive to honor the arbitration agreement in order to develop a reputation as a desirable arbitrator. Because arbitrators who ignore mandatory rules face hittle or no sanction that might offset the incentive to please the parties to the transaction, it should be no surprise that they ignore mandatory rules in favor of the substantive rules contained in the arbitration agreement. Willingness on the part of arbitrators to enforce the rules chosen by the parties, even when these are in conflict with inandatory rules, makes it possible for parties to a transaction to avoid mandatory rules.

To date, the literature on the dilemma of mandatory rules and arbitration has offered no solution that preserves the benefits of arbitration while ensuring that mandatory rules will be enforced. Existing scholarship las concluded that policymakers inust choose between

5. In previous writings, I have commented on the application of securities and antitrust regulation in an international context. See Stephen J. Choi \& Andrew T. Guzman, National Laws, International Money: Regulation in a Global Capital Market, 65 FORDHAM L. REV. 1855 (1997) [hereinafter Choi \& Guzman, National Laws]; Stephen J. Choi \& Andrew T. Guzman, Portable Reciprocity: Rethinking the International Reach of Securities Regulation, 71 S. CAL. L. REv. 903 (1998); Andrew T. Guzman, Capital Market Regulation in Developing Countries: A Proposal, 39 VA. J. INT'L L. 607 (1999) [hereinafter Guzman, Capital Market Regulation]; Andrew T. Guzman, Is International Antitrust Possible?, 73 N.Y.U. L. Rev. 1501 (1998).

6. For present purposes, the incentives of individual arbitrators and arbitration associations are identical. For this reason, the Article will use the term "the arbitrator" to refer to individual arbitrators, arbitral panels, and arbitration associations, as the context requires. 
two policies: one that looks favorably upon arbitration and allows it to proceed witl minimal judicial intervention, but that compromises the ability of the Umited States to enforce mandatory rules, and anotlier that permits substantial judicial review of arbitral awards.?

This Article offers a new solution that permits the enforcement of mandatory rules while allowing arbitration to proceed witl minimal judicial interference. Rather tlian providing for judicial review of arbitration agreements or arbitral rulings, the Article recommends that the parties to the arbitration be given the riglit to sue the arbitrator for a failure to apply a mandatory law. Arbitrator liability imposes a cost on an arbitrator who ignores a mandatory rule-providing an incentive for lier to follow sucli rules. Because this cost is passed on to the parties, arbitrator liability also eliminates the incentive to draft arbitration agreements that purport to ignore mandatory rules. This Article demonstrates that arbitrator liability makes it possible to align the incentives of the arbitrator and the parties witl those of policymakers who want mandatory rules to be applied. Unlike otlier proposals, therefore, arbitrator liability makes it possible to retain the benefits of arbitration witlout compromising inandatory rules.

Part I of this Article discusses American attitudes toward arbitration and explains wly the problem of inandatory rules in arbitration is inore serious than it lias been in the past. The focus in Part I and througlout the Article is international arbitration, but the analysis also applies to the domestic context. Part II explores the mcentives of arbitrators and the parties to a transaction under the current regime,

7. See Thomas E. Carbonneau, The Exuberant Pathway to Quixotic Internationalism: Assessing the Folly of Mitsubishi, 19 VAND. J. TRANSNAT'L L. 265, 297 (1986) (asserting that the doctrine of Mitsubishi does imjustice to the public policy demands of antitrust regulation); Robert B. von Mehren, From Vynior's Case to Mitsubishi: The Future of Arbitration and Public Law, 12 BROOK. J. INT'L L. 583, 627-28 (1986) [heremafter von Mehren, Future of Arbitration] (asserting that arbitrators should be entrusted with public law issues if they are able to establish their neutrality); William W. Park, Private Adjudicators and the Public Interest: The Expanding Scope of International Arbitration, 12 BROOK. J. INT'L L. 629, 630 (1986) (arguing that arbitral awards should be enforced without significant judicial review, eveu at the cost of making mandatory rules default rules); Stephen J. Ware, Default Rules from Mandatory Rules: Privatizing Law Through Arbitration, 83 MINN. L. REV. 703,704 (1999) (stating that courts must either make mandatory rules inarbitrable or require de novo review of arbitral awards that implicate such rules); Christine L. Davitz, Note, U.S. Supreme Court Subordinates Enforcement of Regulatory Statutes to Enforcement of Arbitration Agreements: From the Bremen's License to the Sky Reefer's Edict, 30 VAND. J. TRANSNAT'L L. 59, 95 (1997) (suggesting that the Supreme Court has expanded the Federal Arbitration Act ("FAA") beyond congressional intent). But see Eric A. Posner, Arbitration and Harmonization of International Commercial Law: A Defense of Mitsubishi, 39 VA. J. INT'L L. 647, 651 (1999) (contending that a middle gronnd of randomly reviewing some, but not all, arbitral awards inay be preferable). 
showing that there is a strong incentive to ignore mandatory rules and that there is no reason to expect arbitrators to do otherwise. Even the existimg system of judicial review does hittle to ensure that mandatory rules are enforced. Part III describes arbitrator hability and explains why it corrects the incentive problems created by arbitration in the presence of mandatory rules. It also addresses some potential concerns with arbitrator liability.

\section{ARBITRATION AND ARBITRABILITY}

\section{A. The Problem of Arbitration and Mandatory Rules}

The regnlation of business activity involves both default rules and mandatory rules. As long as the parties to a transaction internalize all the costs and benefits of their activities, default rules are preferable to mandatory rules because the parties will waive a rule only when doing so increases their joint profit. ${ }^{8}$ If they internalize all costs and benefits, the inaximization of joint profits is equivalent to the maximization of societal benefit. ${ }^{9}$ Concern for the externalization of costs or the protection of those who cannot protect themselves, however, can justify the use of mandatory legal rules. ${ }^{10}$ Thus, im areas such as securities regulation, antitrust, intellectual property, and bankruptcy, mandatory laws exist in order to prevent the imposition of costs on the uninformed or on third parties. ${ }^{11}$

8. Although this Article proposes a mechamism for reconciling mandatory laws with arbitration, it is not intended to advocate any particular set of mandatory rules. Evaluation of the merits of specific mandatory rules is beyond the scope of this Article. It will simply be assumed throughout that mandatory laws are adopted only when they are beneficial. Although this is clearly not an accurate assumption, it is adopted in order to abstract away from the substantive question of which mandatory laws should be adopted.

9. See Keith N. Hylton, Agreements to Waive or to Arbitrate Legal Claims: An Economic Analysis, 8 SUP. CT. ECON. REV. (forthcoming 2000) (arguing that waivers and arbitration agreements allow parties to make more efficient use of the threat of hitigation by avoiding it when the costs are higher than the return).

10. Other possible justifications for mandatory rules exist, including, for example, the imability of one party (such as a minor) to give informed consent, the possibility of coerced consent, and notions of faimess. See generally MICHAEL J. TREBILCOCK, THE LIMITS OF FREEDOM OF CONTRACT (1993). In the interests of simplicity and brevity, these alternate justifications are not considered.

11. For the balance of the Article, it will be assuined that mandatory rules are intended to prevent the externalization of costs rather than to protect certain parties to the transaction. This is done only to simplify the discussion. It does not alter any of the results or imtuitions of the paper. 
Because arbitration requires the consent of the parties, an arbitration clause exists only when the parties prefer it to the alternative of dispute resolution before a court. The need for consent implies that when the parties to a transaction are the only ones affected by the transaction-that is, when there are no externalities-any form of dispute resolution upon which the parties agree should be permitted. In this situation, the riglt to judicial resolution of disputes should be a default rule that the parties can waive, and arbitration agreements should be enforced. ${ }^{12}$

If, however, arbitration is used to avoid legal rules that are $\mathrm{m}$ tended to be mandatory, it frustrates rules meant to prevent the externalization of costs onto third parties. If parties are able to avoid mandatory rules in this way, the entire landscape of business regulation is altered because all rules become default rules and the parties are able to externalize inany costs that they would otherwise be forced to internalize. Sucl a scheine undermines inandatory laws designed to bring private costs in line with social costs, and it may reduce social welfare. Part II of this Article demonstrates that under the current system, the parties to a transaction are, indeed, able to convert mandatory laws into default laws through the use of arbitrationmaking the use of arbitration to resolve issues related to mandatory laws problematic.

The problem of nandatory laws and arbitration could be resolved by preventing the arbitration of disputes involving such laws. This approach, however, would present its own costs, because in many cases arbitration offers advantages over traditional litigation. The benefits of arbitration represent welfare gains for society, making a simple ban on arbitration undesirable.

Among these benefits are the cost savings that stem from the fact that an arbitration clause is, above all, a choice-of-forum clause. It allows the parties to avoid most of the uncertainty and delay involved in identifying the jurisdiction that will handle the case. It also allows the parties to select a mutually convenient forum. The absence of such a forum-selection clause nuay impose significant costs on the transaction, includimg the litigation costs associated with determining the correct foruin, the ex ante costs of uncertainty regarding the forum that will ultimately resolve any dispute, and the unnecessary costs of hitigation ì an imconvenient forum. Although a forum-

12. See Hylton, supra note 9. 
selection clause often affects merely procedural rights, it is clear, at least in mternational cases, that the choice of forum can influence the substantive law to be applied. ${ }^{13}$ If the parties are unsure of the apphcable law, they must take into account each of the laws that may apply, reducing the efficiency of their activities. This cost of uncertainty will be particularly important for risk-averse parties whose valuations of projects are reduced by uncertainty.

Arbitration also provides the benefit of an unbiased forum. ${ }^{14} \mathrm{Just}$ as individual states in the United States may be perceived to favor instate litigants over tliose from out of state-a concern that gave rise to diversity jurisdiction in the United States-litigants in an international transaction may fear that foreign courts will be biased in favor of local parties. ${ }^{15}$ Where eacli party is suspicious of the other's courts, and where no alternative dispute resolution procedure exists, some positive net present value transactions may never be carried out. In addition, where a suspicion of bias exists alongside uncertainty regarding the choice of forum, the combination may result in a race to file, im which each party seeks to begin proceedings in its own country. ${ }^{16}$

13. See, e.g., Hartford Fire Ins. Co. v. California, 509 U.S. 764, 770 (1993); Roby v. Corporation of Lloyd's, 996 F.2d 1353, 1355 (2d Cir. 1993).

14. See Samuel A. Haubold, Opting out of the U.S. Legal System-The Case for International Arbitration, SPG-10 INT'L L. PRACTICUM 43, 44-45 (1997) (citing the ability of parties to preselect a neutral forum as one of the advantages of arbitration).

15. The risk of bias is likely to be greater between national court systems than it is between American state courts because the former feature much larger differences in legal rules, legal culture, and background norns. On the topic of bias in U.S. courts, see generally Kevin M. Clermont \& Theodore Eisenberg, Xenophilia in American Courts, 109 HARV. L. REV. 1120 (1996).

16. Although the imtuition that corrupt courts will reduce the number of valuable transactions is correct, it is not as simple as it first appears. In a simple model, for example, a biased court system will not prevent the parties from undertaking a profitable project. Imagine a transaction im which firms from country A and country B can cooperate by investing $\$ 100$ each in period one. This investment yields an expected payoff of $\$ 200$ per firm in period two. Neither firm is able to coinplete the project without the other. If the parties believe disputes will be resolved $\mathrm{m}$ an unbiased forum, they will pursue this valuable opportunity. Suppose, however, that each party believes that the courts in the other party's country are biased. Specifically, each party believes that, should a dispute arise, the other party's courts will award any profit entirely to the local firm, allowing the foreign party to recover only its costs. In period two, therefore, both parties have an incentive to sue in their own jurisdiction, even if there has been no breacl. The resnlt is a race to the courthouse. Despite the fact that both parties, in period one, expect this race, they both will be willing to go forward. As long as each party las some chance of winning the race to the courthouse, both parties receive a positive expected return, making the project worthwhile. (Assume for simphicity that once a suit is filed in one country, the other country's courts will not take jurisdiction. This assunption is not necessary, but it simplifies the 
Additionally, the arbitration of international disputes facilitates the enforcement of subsequent awards. Under the New York Convention, ${ }^{17}$ arbitral awards made in one Convention state are enforceable im any other Convention state on the same basis as domestic arbitral awards, subject to very limited exceptions. ${ }^{18}$ Because virtually every significant commercial nation in the world is a party to the Convention, enforcement of arbitral awards is fairly straightforward. In contrast to this estabhished and well-functioning international enforcement system, there is no global agreement on the enforcement of court judgments. ${ }^{19}$ In fact, the United States is not a party to any treaty regarding the enforcement of judgments. ${ }^{20}$ As a result, arbitral awards are often easier to enforce than court judgments. ${ }^{21}$ The ability to enforce an award at low cost in virtually every country in the world is important im international transactions because the assets of a party

example. In extreme cases in which courts cannot agree on the proper forum, the case must be litigated in both countries, dramatically increasing the costs of the hitigation.) And if one party knows it will always lose the race to the courthouse, it can simply demand a payment up front to cover its costs and profit. When a suit is filed in period two, this party will be able to retain this payment, ensuring a positive return. In this simple example, therefore, the presence of a biased judiciary causes a transfer froin one party to the other ex post. The parties, however, are able to anticipate this outcome and can structure their transaction to take it into account.

In more complex models, however, biased courts inay prevent efficient transactions from takmg place. For exainple, suppose the facts of the above exainple are unchanged, but inagine there is also a third period in which the parties will each receive an additional $\$ 25$. If the game reaches the third period, the parties will race to the courthouse just as they did in the previous example. Recognizing this fact, however, and assuming that each party is equally likely to win the race to file, both parties will prefer to file in period two rather than wait for period three. If party $A$ knows that party $B$ plans to race to file in period three, then party $A$ is better off filing in period two. By filing in period two, party $A$ ensures that he is the first to file and, therefore, receives the benefit of his own court's bias. This strategy will yield a payoff of $\$ 300$, with party $B$ receiving $\$ 100$. If party $A$ were to wait for period three, he would have only a $50 \%$ chance of winning the race to file and, therefore, would expect a payoff of $(0.5)(\$ 350)+(0.5)(\$ 100)=$ $\$ 225$. Of course, both parties face this same incentive, so the race to file takes place ui period two. This resnlt is inefficient because the period-three return of $\$ 50$ is lost. Other reasons why biased courts may lead to inefficient results mclude the existence of litigation costs, which inake it wasteful to try to benefit from one's own court's biases; higli discount rates, which inay prevent long term agreenents; and maccurate perceptions of bias, which can lead to wasteful hitigation.

17. United Nations Convention on the Recognition and Enforcement of Foreign Arbitral Awards, June 10, 1958, 21 U.S.T. 2517, 330 U.N.T.S. 38 [hereinafter New York Convention].

18. See infra note 38 .

19. See Robert B. von Mehren, Enforcement of Foreign Arbitral Awards in the United States, 579 PLI/LIT 147, 153-54.

20. See Russell J. Weintraub, How Substantial Is Our Need for a Judgments-Recognition Convention and What Should We Bargain Away to Get It?, 24 BROOK. J. INT'L L. 167, 168 (1998).

21. See Guzman, Capital Market Regulation, supra note 5, at 632. 
may be located in a jurisdiction that is different from the location of the contract, the location of performance, the party's primcipal place of busmess, or any other jurisdictional touchstone. The New York Convention allows the winning party $\mathrm{m}$ an arbitration to collect on the award regardless of the location of the assets. ${ }^{22}$

Arbitration procedures also are generally more protective of privacy than are judicial procedures. In the context of an imternational transaction, the parties to a dispute may wish to avoid disclosure of the substance of their dispute- or even the existence of a dispute. In addition, the parties may wish to adopt discovery procedures that are more limited than those available under national laws in order to prevent the disclosure of sensitive proprietary information. ${ }^{23}$

Finally, arbitration offers other procedural advantages over judicial dispute resolution. Depending on the specifics of the case, these might include a streamlined set of procedural rules leading to a faster resolution of disputes, a more limited right to appeal, and lower hitigation costs. ${ }^{24}$

\section{B. The Federal Arbitration Act and the New York Convention}

Although U.S. courts currently have a favorable view of arbitration and stand willing to enforce arbitration clauses and arbitral awards in a wide variety of contexts, it has not always been so. For most of the nimeteenth century, courts permitted arbitration and were willing to enforce arbitral awards, ${ }^{25}$ but parties were never coinpelled to arbitrate their claims. Arbitration required the consent of both parties after the dispute had arisen. Arbitration clauses contained in the contract were considered to be revocable at will, implying that parties were unable, at the time of contracting, to commit to arbitration. ${ }^{26}$ Under a regime in which precommitment to arbitration was not permitted, the willingness of arbitrators to apply mandatory rules was not an issue. A party that stood to benefit from a mandatory rule could ensure its apphication by refusing to arbitrate before an arbitra-

22. See New York Convention, supra note 17, art. III, 21 U.S.T. at 2519, 330 U.N.T.S. at 40.

23. See Haubold, supra note 14 , at 43 .

24. In addition to the above list of private benefits, arbitration also has positive effects on the overall judicial system. It reduces the burden on courts and helps resolve choice-of-law issues that would be difficult for courts to handle consistently across jurisdictions.

25. See, e.g., Karthaus v. Yllas y Ferrer, 26 U.S. (1 Pet.) 222, 228 (1828).

26. See von Mehren, Future of Arbitration, supra note 7, at 589-90 (reviewing the 19thcentury Supreme Court rejection of contract arbitration clauses for future disputes). 
tor who was expected to ignore the rule. A refusal to arbitrate, of course, would bring the dispute before a court. At the time of contracting, therefore, both parties would know that the mandatory rule would be applied, and the contract would be completed under that assumption. Furtherinore, arbitrators wishing to attract busmess would have an incentive to develop a reputation for enforcing mandatory rules rather than the law cliosen in the arbitration agreement. The use of arbitration to avoid inandatory rules was simply not possible without judicial enforcement of binding, irrevocable arbitration clauses.

In 1925, Congress passed the Federal Arbitration Act ("FAA"). ${ }^{27}$ The FAA imstructs courts that an agreement to arbitrate is "valid, irrevocable, and enforceable." ${ }^{28}$ If there is an arbitration clause, the FAA provides thiat, at the request of one of the parties, the court must refuse to hear the case, forcing the reluctant party into arbitration. ${ }^{29}$ In the international context, an agreement to arbitrate is also supported by the New York Convention, under which such agreements are bimding and domestic courts are required to refuse a judicial hearing to parties that have a contractual commitment to arbitrate an issue..$^{30} \mathrm{~A}$ party that lias consented to arbitration through an arbitration agreement, therefore, calmot later demand a judicial resolution of an arbitral issue. ${ }^{31}$

In addition to making arbitration clauses enforceable, the FAA emphasizes that courts must show deference to arbitral rulings. The

27. Act of Feb. 12, 1925, ch. 213, 43 Stat. 883 (codified at 9 U.S.C. $\$ \S 1-4$ (1994)).

28. 9 U.S.C. $\$ 2(1994)$.

29. See id. $\$ \$ 3-4$.

30. See New York Convention, supra note 17, arts. I, III, 21 U.S.T. at 2519, 330 U.N.T.S. at 38,40 .

31. Certain areas of law are deemed inarbitrable on the ground that they implicate public policy questions that sliould be decided through the public system of dispute resolution ratlier than through a private process. An alternative interpretation of the arbitrability issue is that certain issues should be resolved by courts because there are third-party effects that the parties to a transaction will not take into account. The question of arbitrability has generally been a matter for donestic determination rather than international agreement. United States courts, at various times, have found each of the following areas to be inarbitrable: the Securities Act of 1933, see Wilko v. Swan, 346 U.S. 427, 438 (1953); the Civil Rights Act, see Utley v. Goldman Saclis \& Co., 883 F.2d 184, 187 (1st Cir. 1989); RICO claims, see Page v. Moseley, Hallgarten, Estabrook \& Weeden, Inc., 806 F.2d 291, 298-300 (1st Cir. 1986); ERISA claims, see Barrowclough v. Kidder, Peabody \& Co., 752 F.2d 923, 941 (3d Cir. 1985); bankruptcy matters, see Zimmerman v. Continental Airlines, 712 F.2d 55, 59 (3d Cir. 1983); the antitrust laws, see American Safety Equip. Corp. v. J.P. Maguire, 391 F.2d 821, 822 (2d Cir. 1968); patents, see Beckman Instruments, Inc. v. Technical Dev. Corp., 433 F.2d 55, 63 (7th Cir. 1970); and the Commodities Exchange Act, see Breyer v. First Nat'l Monetary Corp., 548 F. Supp. 955, 959 (D.N.J. 1982); see also Ware, supra note 7, at 713-14 (collecting cases). 
Act lists only four grounds upon which an arbitral ruling may be vacated, all of whicl turn on corruption, ${ }^{32}$ fraud ${ }^{33}$ or arbitrator misbehavior. ${ }^{34}$ In addition, there are three grounds on which courts may modify or correct an award, but these require a mistake, ${ }^{35}$ an award on a matter not submitted to the arbitrator, ${ }^{36}$ or an award that is "imperfect in matter of form not affecting the merits of the controversy." 37 The New York Convention imposes on courts a similar obligation to recognize and enforce awards, subject to a similarly narrow set of exceptions. ${ }^{38}$

Judicial enforcement of arbitration agreements and subsequent arbitral awards opens the door to abuse by arbitrators and the parties to arbitrations. Because there is only minimal judicial oversight of arbitration, arbitrators may clioose to ignore rules of law that are intended to be inandatory. If the use of arbitration were restricted to traditional private law disputes, as was generally the case through the 1960 s, ${ }^{39}$ the risk of misconduct would be small because such disputes are typically (thougl not exclusively) governed by default rules ratlier than inandatory rules. When arbitration is also used to settle disputes

32. See 9 U.S.C. \$ 10(a)(1) (1994); see also Standard Tankers (Bahamas) Co. v. Motor Tank Vessel, Akti, 438 F. Supp. 153, 160 (E.D.N.C. 1977) ("To constitute evident partiality, some overt misconduct or demonstration of partiality is required.").

33. See 9 U.S.C. \$ 10(a)(1); see also Lafarge Conseils et Etudes, S.A. v. Kaiser Cement \& Gypsum Corp., 791 F.2d 1334, 1339 (9th Cir. 1986) (holding that, in order to vacate an arbitration award on the basis of fraud, a inovant inust show "that the fraud was (1) not discoverable upon the exercise of due diligence prior to the arbitration, (2) inaterially related to an issue in the arbitration, and (3) established by clear and convincing evidence").

34. See 9 U.S.C. $\$ 10(a)(2)-(4)$; see also Allendale Nursing Home, Inc. v. Local 1115 Joint Bd., 377 F. Supp. 1208, 1214 (S.D.N.Y. 1974) (liolding that the refusal of an arbitrator to grant the requested adjournment when the arbitrator was clearly aware of the bona fide and serious illness of a party's key witness was sufficient to vitiate the arbitrator's award); Riko Enters. v. Seattle Supersomics Corp., 357 F. Supp. 521, 526 (S.D.N.Y. 1973) (vacating the award granted by a commissioner of a professional basketball league who was acting as an arbitrator where testimony showed that he "conducted no hearing and did not allow... [the party charged] to submit any evidence to rebut the charges").

35. See 9 U.S.C. \$11(a) (1994).

36. See id. $\$ 11(b)$.

37. Id. $\$ 11$ (c).

38. The Convention provides that recognition and enforcement of an award may be refused if the arbitration agreement is not valid under the applicable law, if there was a lack of notice, if the dispute did not fall within the ternns of the submission to arbitration, if the composition of the arbitral authority or procedure was not in accordance with the law or the arbitration agreement, if the award lias been set aside, if the dispute was marbitrable, or if recognition of the award would be contrary to public pohcy. See New York Convention, supra note 17, art. V, 21 U.S.T. at 2520,330 U.N.T.S. at $40,42$.

39. See infra note 41 . 
imphicating traditional public law issues, however, there is a greater risk that mandatory laws will be implicated and that arbitrators will clioose not to enforce those laws. The next section presents two important examples of how the courts lhave expanded the concept of arbitrability to include public law issues.

\section{The Expanding Boundaries of Arbitrability}

As previously mentioned, arbitration historically lias been a dispute resolution meclianism for transactions that implicate only private law. ${ }^{40}$ Public law disputes were left witlim the exclusive domain of courts. ${ }^{41}$ In recent years, however, courts liave expanded the category of arbitrable disputes to include issues that are normally considered questions of public law and that previously lad been inarbitrable. This section provides a brief description of two areas in which this expansion has been both dramatic and controversial-securities and antitrust.

1. Arbitration of Claims Under the Securities Laws. A discussiou of the arbitrability of securities laws in the Uinted States must start with Wilko v. Swan. ${ }^{42}$ In that case, the plaintiff brouglit suit in federal district court against the partners in a securities brokerage firm, alleging violations of section 12(2) of the Securities Act of 1933. ${ }^{43}$ The essence of the claim was that the plaintiff was fraudulently induced to purcliase shares in a company called Air Associates, Inc. The plaintiff alleged that the defendants had made false representations regarding the future value of the sliares and had failed to disclose that a director of Air Associates was selling his own stock. ${ }^{44}$

The defendants in the suit noved to stay the trial pursuant to the $\mathrm{FAA}^{45}$ relying on an arbitration agreement signed by the parties at the time of the sale of the securities. The question before the court was whether securities disputes were arbitrable. The main legal justification for determining that the issue was inarbitrable was language from the Securities Act stating that "[a]ny condition, stipulation, or

40. See Davitz, supra note 7, at 62-63.

41. See Park, supra note 7, at 636-37.

42. 346 U.S. 427 (1953).

43. See id. at 428 .

44. See id. at 429 .

45. See id.; see also 9 U.S.C. $\$ 3$ (1994) (providing for a stay of court proceedings where the issue is deemed referable to arbitration). 
provision binding any person acquiring any security to waive coinpliance with any provision of this subchapter or of the rules and regulations of the Commission shall be void." ${ }^{46}$

The question for the court, therefore, was whether an agreement to arbitrate future disputes was such a condition-one that would waive coinpliance with one or nore provisions of the Securities Act. The district court concluded that such disputes were not amenable to arbitration, ${ }^{47}$ but its decision was subsequently reversed by the Court of Appeals for the Second Circuit. ${ }^{48}$ The Supreme Court granted certiorari. $^{49}$

The Supreme Court lield that disputes under the Securities Act were not arbitrable, concluding that "the right to select the judicial forum [including arbitration] is the kind of 'provision' that cannot be waived under section 14 of the Securities Act." ${ }^{50}$ The Court reasoned that the Securities Act was drafted in order to protect buyers of securities who liave less opportunity to investigate the securities than do the sellers and who, therefore, are at a disadvantage. In giving up his right to a court proceeding, the buyer "surrenders one of the advantages the [Securities] Act gives him and surrenders it at a time when he is less able to judge the weight of the handicap the Securities Act places upon his adversary."

The Wilko opinion suggests that one of the concerns of the Court was the ability of the arbitrators to apply inandatory rules accurately:

[T]heir award may be made without explanation of their reasons and without a complete record of their proceedings, the arbitrators' conception of the legal meaning of such statutory requirements as "burden of proof," "reasonable care" or "material fact," cannot be examined.... While it may be true ... that a failure of the arbitrators to decide in accordance with the provisions of the Securities Act would "constitute grounds for vacating the award pursuant to sec-

46. 15 U.S.C. $\$ 77 n$ (1994).

47. See Wilko v. Swan, 107 F. Supp. 75, 79 (S.D.N.Y. 1952), rev'd, 201 F.2d 439 (2d Cir.), rev'd, 346 U.S. 427 (1953).

48. See Wilko v. Swan, 201 F.2d 439, 445 (2d Cir.), rev'd, 346 U.S. 427 (1953) (stating that the congressional policy of protecting investors, reflected in the Securities Act of 1933, did not override a congressional policy favoring arbitration, evidenced in the FAA, particularly when the parties so agreed).

49. See Wilko, 346 U.S. at 430.

50. Id. at 435 .

51. Id. 
tion 10 of the Federal Arbitration Act," that failure would need to be made clearly to appear. ${ }^{52}$

This statement by the Court foreshadows many of the criticisms that would later be leveled against the Supreme Court's decision in Mitsubishi Motors Corp. v. Soler Chrysler-Plymouth, ${ }^{53}$ the most prominent case $\mathrm{m}$ the debate surrounding mandatory rules and arbitration. ${ }^{54}$

Although Wilko appeared to provide a clear and binding precedent on the arbitrability question as applied to securities, the issue was once again before the Court some twenty years later in Scherk $v$. Alberto-Culver Co. ${ }^{55}$ Unlike Wilko, Scherk dealt with an international securities transaction. A German plaintiff, Scherk, agreed to sell his busmess to an American company, Alberto-Culver. Alberto-Culver later filed suit in U.S. district court, alleging that Scherk had violated antifraud rules contained im section 10(b) of the Securities Exchange Act of 1934 and Rule $10 \mathrm{~b}-5$ of the SEC regulations. ${ }^{56}$ Sclierk responded with a motion to dismiss, relying on, anong otler arguments, the existence of an arbitration clause calling for arbitration in Paris under International Chamber of Cominerce rules. ${ }^{57}$

Following Wilko v. Swan, the district court rejected Scherk's notion to dismiss. ${ }^{58}$ The Seventh Circuit affirmed, also citing Wilko. ${ }^{59}$ The Supreme Court, however, distmgnished Wilko and upheld the arbitration clause. ${ }^{60}$ The key difference between the cases, according to the Court, was that the Scherk case involved a "truly international agreement." ${ }^{61}$ In the absence of an arbitration clause or soine other choice-of-forum clause, the Court reasoned, parties to international transactions of this type camiot be certain of the law that will apply.

\footnotetext{
52. Id. at $\mathbf{4 3 6}$ (citations omitted).

53. 473 U.S. 614 (1985).

54. See infra note 83 and accompanying text.

55. 417 U.S. 506 (1974).

56. See id. at 509 .

57. See Alberto-Culver Co. v. Scherk, 484 F.2d 611, 614 (7th Cir. 1973), rev'd, 417 U.S. 506

58. See Scherk, 417 U.S. at 510.

59. See Scherk, 484 F.2d at 619.

60. See Scherk, 417 U.S. at 519-20 ("We hold that the agreement of the parties ... to arbitrate any dispute arising out of their international commercial transaction is to be respected and enforced by the federal courts in accord with the explicit provisions of the Arbitration Act."). Justice Stewart wrote the opinion of the Court. Justice Douglas wrote a dissent, im which Justices Brennan, White, and Marshall joined. See id. at 521 (Douglas, J., dissenting).
} (1974).

61. Id. at 515 . 
Choice-of-law and choice-of-forum clauses, therefore, are necessary to reduce the uncertainty surroundimg the transaction. ${ }^{62}$ The Court further observed, "A parochial refusal by the courts of one country to enforce an international arbitration agreenent would not only frustrate these purposes [of orderliness and predictability], but would invite unseemly and mutually destructive jockeying by the parties to secure tactical hitigation advantages." ${ }^{63}$

The Scherk decision opened the door to the arbitration of international securities transactions. Resistance to arbitration in domestic transactions was eventually abandoned in the late 1980s. In Shearson/American Express v. McMahon ${ }^{64}$ the Supreme Court permitted arbitration of a domestic securities dispute, reasoning that arbitration represents merely a choice of forum and that "there is no reason to assume at the outset that arbitrators will not follow the law." McMahon Court stopped short of overruling Wilko, but the Court took this final step in 1989, in Rodriguez de Quijas v. Shearson/American Express. ${ }^{66}$ By 1990, therefore, there was no serious doubt that securities disputes were arbitrable and that courts should enforce arbitration agreements as well as arbitral awards. ${ }^{67}$

62. See id. at 518. The Court also included language suggesting that the United States must become more flexible in dealing with international issues: "We cannot have trade and coininerce im world markets and international waters exclusively on our terms, governed by our laws, and resolved in our courts." Id. at 519.

63. Id. at 516 .

64. 482 U.S. 220 (1987).

65. Id. at 232 .

66. 490 U.S. 477 (1989).

67. The most recent developments in the area of party choice in securities have dealt more exphicitly with the choice-of-law question. In a series of cases involving Lloyd's of London, various circuit courts have ruled that choice-of-law provisions will sometimes be upheld. Although the precise test varies from circuit to circuit, the Second Circuit's test is representative. In Roby' v. Corporation of Lloyd's, 996 F.2d 1353 (2d Cir. 1993), the Second Circuit held that forumselection and choice-of-law clauses are presumptively vahd and that to overcone this presumption "it is not enough that the foreign law or procedure be different or less favorable than that of the United States. Instead, the question is whether the apphication of the foreign law presents a danger that the Roby Names 'will be deprived of any remedy or treated unfairly." Id. at 1363 (internal citations omitted). Similar holdings have coine out of the Fourth, Fifth, Sixth, Seventh, Ninth, Tenth, and Eleventh Circuits. See Lipcon v. Underwriters at Lloyd's, London, 148 F.3d 1285 (11th Cir. 1998); Richards v. Lloyd's of London, 135 F.3d 1289 (9th Cir. 1998); Haynsworth v. The Corp., 121 F.3d 956 (5th Cir. 1997); Allen v. Lloyd's of London, 94 F.3d 923 (4th Cir. 1996); Shell v. R.W. Sturge, Ltd., 55 F.3d 1227 (6th Cir. 1995); Bonny v. Society of Lloyd's, 3 F.3d 156 (7th Cir. 1993); Riley v. Kingsley Underwriting Agencies, Ltd., 969 F.2d 953 (10th Cir. 1992). 
2. Arbitration of Antitrust Claims. Although securities regulation is the backdrop for several important arbitrability decisions, the single inost influential case for the purposes of this Article, Mitsubishi Motors Corp. v. Soler Chrysler-Plymouth, Inc., dealt with an antitrust issue. In 1979, Soler Chrysler-Plymouth ("Soler") entered into a distributor agreement with Chrysler International, S.A. ("CISA") for the sale of Mitsubishi-manufactured vehicles within a specified area. ${ }^{68}$ On the same day, Soler, CISA, and Mitsubishi Motors Corporation ("Mitsubishi") entered into a sales agreement providing for the sale of Mitsubishi products to Soler. Included in the sales agreement was an arbitration clause providing for arbitration, im Japan, of all disputes between Soler and Mitsubishi under the rules of the Japan Commercial Arbitration Association. ${ }^{69}$

Although the relationship proved profitable for a short time, by 1981 the parties were at odds, and Mitsubishi filed a petition in federal district court seeking an order compelling arbitration. Soler counterclaimed against both Mitsubishi and CISA, alleging violations of the Sherman Act. ${ }^{70}$

The question before the court was whether a federal antitrust claim arising from an international transaction was arbitrable. In the eyes of the district court, which rehed on Scherk, the international nature of the transaction required enforcement of the arbitration agreement, even as to the federal antitrust claims. ${ }^{71}$ The Court of Appeals for the First Circuit reversed the district court with respect to the arbitrability of federal antitrust claims, holding that Soler's counterclaims were not arbitrable. ${ }^{72}$ In support of its holding, the court cited American Safety Equip. Corp. v. J.P. Maguire \& Co. ${ }^{73}$ which at the time was the leading case on the question of arbitrability of antitrust claims. Among the reasons the American Safety court advanced for the inarbitrability of antitrust claims was the fact that "[a] claim under the antitrust laws is not merely a private matter.... [T] he

68. See Mitsubishi Motors Corp. v. Soler Chrysler-Plymouth, Inc., 473 U.S. 614, 617 (1985). On the arbitrability of domestic antitrust claims, see Syscomm Int'l Corp. v. Synoptics Communications, Inc., 856 F. Supp. 135 (E.D.N.Y. 1994) (holding that antitrust claims arising from domestic transactions are arbitrable).

69. See Mitsubishi, 473 U.S. at 617.

70. See id. at 617-20; see also 15 U.S.C. $\$ \$ 1-7$ (1994).

71. See Mitsubishi, 473 U.S. at 621.

72. See Mitsubishi Motors Corp. v. Soler Chrysler-Plymouth, Inc., 723 F.2d 155, 162 (1st Cir. 1983), rev'd 473 U.S. 614 (1985).

73. 391 F.2d 821 (2d Cir. 1968), cited in Mitsubishi, 723 F.2d at 162. 
plaintiff asserting his rights under the Act has been likened to a private attorney-general who protects the public's interest." ${ }^{14}$ In addition to accepting the public policy claims of American Safety, the circuit court in Mitsubishi had to reconcile its decision with the obhigations of the United States under the New York Convention. It did so by interpreting the New York Convention's requirement that each contracting state recognize arbitration agreements "concerning a subject matter capable of settlement by arbitration" to imply a public policy exception. ${ }^{75}$

The Supreme Court granted certiorari on the question of "whether an American court should enforce an agreement to resolve antitrust claims by arbitration when that agreement arises from an international transaction." ${ }^{.76}$ The Court noted the strong presumption, established by the FAA, in favor of enforcing arbitration agreements, and it cited Scherk for the proposition that there is also a strong judicial presumption in favor of forun-selection clauses. ${ }^{\text {T }}$ The Court also noted the accession of the United States to the New York Convention to underscore the importance of enforcing arbitration agreenients in international transactions. ${ }^{78}$

Over a strong dissent, ${ }^{79}$ the inajority held that the arbitration clause must be enforced, concluding that "concerns of international comity, respect for the capacities of foreign ... tribunals, and sensitivity to the need of the international commercial system for predictability in the resolution of disputes require that we enforce the parties' agreement, even assuming that a contrary result would be forthcoming in a donrestic context." ${ }^{, 80}$ Thus, antitrust disputes, like securities disputes, are considered arbitrable, at least when they arise within an international transaction. The Court noted, however, that

74. American Safety, 391 F.2d at 826.

75. New York Convention, supra note 17, art. II(1), 21 U.S.T. at 2519, 330 U.N.T.S. at 38 (emphasis added); see Mitsubishi, 473 U.S. at 638.

76. Mitsubishi, 723 F.2d at 164-66.

77. See Mitsubishi, 473 U.S. at 631. The Court also cited The Bremen v. Zapata Off-Shore Co., 407 U.S. 1 (1972), to support the claim that forum-selection clauses are to be enforced. See Mitsubishi, 473 U.S. at 629-30.

78. See Mitsubishi, 473 U.S. at 631 :

Scherk establish[ed] a strong presumption in favor of enforcement of freely negotiated contractual choice-of-forum provisions .... [T] That presumption is reinforced by the emphatic federal pohicy in favor of arbitral dispute resolution. At least since this Nation's accession in 1970 to the Convention ... that federal pohcy applies with special force in the field of imternational commerce.

79. See infra note 83 and accompanying text.

80. Mitsubishi, 473 U.S. at 629. 
where the arbitration agreement includes claims under U.S. antitrust law, "the tribunal ... should be bound to decide that dispute in accord with the national law giving rise to the claim." ${ }^{81}$

The difficulty with the Court's position, of course, is that there is no guarantee that the arbitrators will, im fact, apply U.S. antitrust laws to the dispute. Recognizing the problem, the Court attempted to explain its position in the much debated and criticized "footnote 19," which reads in part:

We therefore have no occasion to speculate on [the choice-of-law] matter at this stage in the proceedings, when Mitsubishi seeks to enforce the agreement to arbitrate, not to enforce an award. Nor need we consider now the effect of an arbitral tribunal's failure to take cognizance of the statutory cause of action on the claimant's capacity to reinitiate suit in federal court. We merely note that in the event the choice-of-forum and choice-of-law clauses operated in tandem as a prospective waiver of a party's right to pursue statutory remedies for antitrust violations, we would have hittle hesitation in condemning the agreement as against public pohicy. ${ }^{82}$

The footnote has been criticized for its failure to provide guidance to future courts regarding the enforceability of arbitration clauses in antitrust cases. ${ }^{83}$ On the one hand, it indicates that arbitrators are to be given the benefit of the doubt and that arbitration agreements should be enforced. On the other hand, it imdicates that such agreements will not be enforced when they represent a "prospective waiver" of U.S. law.

\section{INCENTIVES UNDER THE STATUS QUO}

This part undertakes an analysis of the incentives of both the parties to a transaction and the arbitrator, demonstrating that both have an incentive to treat mandatory rules as default rules. In addition, it shows that judicial review-whether the existing form or one

81. Id. at $636-37$.

82. Id. at $637 \mathrm{n} .19$.

83. See id. at 646 (Stevens, J., dissenting) ("The plain language of this statute encompasses claims that arise out of its contract ... but does not encompass a claim arising under federal law... Nothing in the text of the 1925 Act, nor its legislative history, suggests that Congress intended to authorize the arbitration of any statutory claims."); Joseph D. Becker, Antitrust and International Arbitration-The New American Synthesis, INT'L BUS. LAw., Nov. 1985, at 447 ("The Court's acceptance of the propositions that foreign arbitrators will respect treble damage claims, that they will enforce American antitrust law where applicable, and that their omissions may be corrected at the award enforceinent stage will strike soine as so much Micawberism."). 
of the potential alternatives-fails to deal with the problem of mandatory rules in arbitration. Arbitration, coupled with limited judicial review, frustrates the intent of lawmakers to make certain legal rules inandatory. ${ }^{84}$

\section{A. The Parties to the Transaction}

Consider first the incentives of the parties to the transaction. Once the parties agree, in principle, to complete a transaction, their primary objective is to reduce its costs. Doing so allows them to increase the joint gains of the transaction, which can then be divided between them. ${ }^{85}$ To this end, they select not only the terms of the exchange, snch as sales price and dehvery terms, but also, to the extent they are able, the law to be apphed and the forum im which disputes are to be settled. One of the options available to the parties is a contract clause calling for the settlement of disputes before an arbitrator rather than a court. ${ }^{86}$ If the parties select arbitration, they are also able to select a variety of procedural rnles, including a mechanism for the selection of an arbitrator.

To the extent that the parties are able to choose the rules of the arbitration, including the identity of the arbitrator, they will again make the cost-minimizing choice. If they are able, through a careful selection of an arbitrator, to avoid a inandatory rule whose costs to the parties exceed its benefits, they will do so. Note that because the parties seek to minimize their joint costs, even rules that offer one of them substantial benefits will be avoided if the joint costs of the rule outweigh its benefits. To see why this is so, consider the following example.

Example. Imagine a securities transaction between two parties: an investor who is a U.S. resident and an issuer that is a British firm. Assume that the transaction falls under the jurisdictional reach of the antifraud rules contained in section 10(b) of the Securities Ex-

84. See generally Ware, supra note 7, at 703 (arguing that arbitration has made many mandatory rules de facto default rules).

85. There are a variety of reasons why one or more parties to a transaction may not seek to minimize transactions costs. These imclude, for example, hold-up opportumities, reputational concerns, and strategic behavior. I put these issues aside in the interests of simplicity. Including them would not affect the general point that parties will choose arbitration when it offers them some ex ante advantage over a judicial resolution of their disputes.

86. See Hylton, supra note 9. 
change Act and SEC Rule $10 \mathrm{~b}-5 .{ }^{87}$ For the investor, the protection of U.S. antifraud rules has value because it reduces the risk she bears when she invests in the security. For simphicity, assume that she values the protection of these rules at $\$ 100$. For the issuer, on the other hand, exposure to these antifraud rules represents a cost. If these rules apply to the transaction, the issuer faces potential hability, not only for meritorious suits should it commit fraud, but also for strike suits. ${ }^{88}$ Assume that these antifraud rules represent a cost of $\$ 150$ to the issuer. Suppose that the application of the antifraud rules can be avoided through the use of arbitration. When the issuer and investor negotiate the terms of their transaction, ${ }^{90}$ the investor will be willing to accept an arbitration agreement that includes a waiver of her right to remedies under Rule $10 \mathrm{~b}-5$ only if she is compensated. To get her to consent to arbitration, the issuer will have to provide compensation that is at least equal to the $\$ 100$ value she places on the protection of the antifraud rules. Because the cost imposed on the issuer exceeds the benefits the rules provide to the investor, it is worthwhile for the issuer to offer sufficient compensation to get the investor's consent to arbitration. By offering some amount between $\$ 100$ and $\$ 150$, the issuer can get the consent of the investor to arbitration and a waiver of the antifraud rules. The arbitration agreement reduces the total costs of the transaction, and the transfer ensures that both parties are better off.

The above discussion and example demonstrate that the parties will seek, at the time of contracting, to avoid any rule that imposes a net cost. After a dispute arises, however, the interests of the parties may change. A party that consented to a waiver of a mandatory rule

87. For a discussion of the reach of the U.S. antifraud rules, see Stephen J. Choi \& Andrew T. Guzman, The Dangerous Extraterritoriality of American Securities Laws, 17 Nw. J. INT'L L. \& BUS. 207, 215-19 (1996).

88. See generally James Bohn \& Stephen Choi, Fraud in the New-Issues Market: Empirical Evidence on Securities Class Actions, 144 U. PA. L. REV. 903 (presenting empirical evidence that most securities fraud class actions are strike suits).

89. See, e.g., Roby v. Corporation of Lloyd's, 996 F.2d 1353, 1357-58 (2d Cir. 1993). In that case, an arbitration agreement was signed between "Names" (investors) and "Member's Agents" (investor representatives within Lloyd's). See id. at 1358. The arbitration agreement called for the application of English law, despite the fact that some of the Names were American and that "mandatory" U.S. securities laws would apply absent the arbitration clause. See id. The Second Circuit found the arbitration clause, mcluding the choice-of-law portion, to be enforceable. See id. at 1366.

90. In a public issue, of course, the issuer and the imvestor rarely negotiate directly. Nevertheless, there is a form of implicit negotiation inasmuch as the issuer chooses the terms on which it is prepared to offer the securities and the investor chooses whether to accept those terms. Because the issuer wants the highest possible price for its securities, it will seek to provide terms that suit the needs of the investor. 
at the time of contracting may wish to liave that rule applied once a dispute arises. In otler words, a party may be prepared to contract out of a rule ex ante, but, once a dispute arises, the party may seek to revoke lier waiver of riglits. Because botlı parties recognize tliat one of them may wish to revoke a waiver of riglits after a dispute arises, the initial waiver will be valuable to the parties only if it is irrevocable and enforceable. ${ }^{91}$ Prior to the FAA, agreements to arbitrate were revocable. ${ }^{92}$ When a dispute arose, either party could revoke its agreement to arbitrate and demand a judicial resolution of the dispute. In that environment, agreements to arbitrate liad little value because both parties recognized that the agreement did not represent a credible commitment. Thus, an attempt to avoid a mandatory rule tlirough the use of arbitration will only succeed if (i) the agreement to arbitrate is enforced by a court, (ii) the arbitrator is willing to ignore the mandatory law im question, and (iii) the arbitral award can subsequently be enforced over objections from the losing party. This poimt is illustrated in the following example.

Example. Returning to the previous example, the investor may be prepared to waive the protections of the antifraud rules in exchange for some compensation at the time of contracting, but should a dispute arise in which the imvestor can profit from application of the antifraud rules, she will seek to liave thein apphed. In other words, if she is permitted to do so, she will revoke her earher waiver. Because the waiver of the antifraud rules was achieved through an arbitration clause, the investor may seek to avoid the arbitration. If this fails, she may try to get the arbitrator to apply the supposedly mandatory antifraud rules, $m$ contravention of the original intent of the parties. If this too fails, she can try to prevent the enforcement of the award by a court. If it is known that these avenues are all foreclosed to the investor, her original commitment to accept arbitration as a mechamism to waive the antifraud rules is credible, and the issuer will be willing to offer her compensation for doing so. If, on the other hand, it is known that she will be able to avoid arbitration, get the arbitrator to apply the mandatory rules, or prevent enforceinent of the award, her initial agreement to waive the antifraud rules through ar-

91. The waiver need not be fully enforceable, but it must be enforceable at least some of the time. A waiver that is enforced some, but not all, of the time is valuable to the parties because it allows them to avoid the relevant mandatory rules with some probability. Given that the parties wish to avoid these rules, they prefer a waiver that avoids the rules some of the time to one that never does so.

92. See supra Part I.B. 
bitration will not be credible, and the issuer will be unwilling to offer her compensation for her agreement to arbitrate.

Under existing law, when a party consents to have future disputes settled through arbitration, she waives her right to deinand that such disputes be litigated before a court. The FAA instructs courts to enforce arbitration agreements, thereby closing the courthouse doors to a party that has consented to arbitration of an arbitrable claim. ${ }^{93}$ Similarly, the FAA places strict limits on the ability of a court to overturn an arbitral award. ${ }^{94}$ Finally, courts are reluctant to conduct a detailed review of arbitral awards. ${ }^{95}$ From the point of view of the parties, the law makes agreements to arbitrate enforceable and irrevocable and permits the enforceinent of arbitral awards. Therefore, as long as the parties can find a cooperative arbitrator, they will be able to reduce the cost of their transaction through an arbitration agreement that includes a waiver of mandatory rules that impose a net cost on the transaction.

\section{B. The Arbitrator}

Now consider the incentives of arbitrators. In at least some corners, it is beheved that arbitrators have a duty to apply mandatory rules. For example, the Mitsubishi Court stated that arbitrators have an obhigation to resolve disputes according to national laws. ${ }^{\infty}$ In addition, commentators have from time to time observed that arbitrators must not only be neutral as between the parties, but also inust not favor the intent of the parties over nonwaivable requirements of public law. ${ }^{97}$ The acadeumc hiterature, however, has rarely addressed the

93. See 9 U.S.C. $\$ 2$ (1994) ("A written provision in ... a contract evidencing a transaction involving commerce to settle by arbitration a controversy thereafter arising out of such contract ... shall be valid, irrevocable, and enforceable, save upon such grounds as exist at law or in equity for the revocation of any contract."); id. $\S 4$ ("A party aggrieved by the alleged failure, neglect, or refusal of another to arbitrate under a written agreeinent for arbitration may petition [a] United States district court which .... shall make an order directing the parties to proceed to arbitration in accordance with the terms of the agreenient.").

94. See id. $\$ 10$.

95. See Mitsubishi Motors Corp. v. Soler Chrysler-Plymouth, Inc., 473 U.S. 614, 634-38 (1985) ("[T]he efficacy of [the] arbitral process requires that substantial review at the award enforcenıent stage remain minimal ....").

96. See id. at 636-37.

97. See, e.g., von Mehren, Future of Arbitration, supra note 7, at 627 ("[E]specially in the pubhic law area arbitrators should not be advocates for the position of those who appoint thein."); Detlev Vagts, National Legal Systems and Private Dispute Resolution, 82 AM. J. INT'L 
question of whether it is reasonable to expect arbitrators to respect mandatory laws. ${ }^{98}$ If arbitrators, indeed, have sufficient incentive to apply these rules, the problem of inandatory rules in arbitration largely disappears. Once a dispute reaches arbitration, the mandatory law in question will be put before the arbitrator by the party that stands to benefit from its apphication. ${ }^{99}$ Disputes will be resolved in accordance with the law, the parties will get the benefits of arbitration, and there will be no conflict between inandatory rules and arbitration. Furthermore, if arbitrators consistently apply mandatory rules, efforts to avoid mandatory rules through an agreement to arbitrate will fail-eliminating the incentive to make such agreements. ${ }^{100}$

In order to understand the behavior of arbitrators, it is helpful to begin by noting that although the arbitrator performs a task that resembles that of a judge, there are critical differences between judges and arbitrators. Despite the resemblance between arbitration proceedings and court proceedings, it is important to keep in inind that the former is the result of a private contract while the latter arises from the state's authority to resolve disputes and to compel comph-

L. 616, 620 (1988) (reviewing INTERNATIONAL COMMERCIAL ARBITRATION IN NEW YORK (J. Stewart McClendon \& Rosabel E. Everard Goodman eds., 1986)):

Increasingly, arbitrators face a double bind: whether to give effect to the will of the parties, or to protect the reputation of the arbitral process by refusing to let it be used to evade the mandatory norms of a country with a vital interest in the subject matter of the dispute.

98. See Posner, supra note 7, at 664 ("The arbitrators face a collective action problem: they are better off if all respect the inandatory rule, but each has an imcentive to deviate.").

99. It is possible that in a particular dispute neither party wishes to have the inandatory rule apply and that it will never be raised. This problem, however, is not unique to arbitration. In a judicial proceeding, the court rehes on the parties to raise arguments, and it will normally consider only those issues raised by one of the parties. Where mandatory laws are also enforced by admunistrative agencies, of course, these agencies may challenge comphance with a mandatory rule, but the behavior of such agencies is not relevant to the current discussion. It is also possible that arbitrators are simply less qualified or less capable in the application of mandatory rules than are judges. This concern, however, goes beyond the scope of this Article. If arbitrators are less quahified than judges, this represents an imdependent reason to oppose the arbitrability of mandatory rules.

100. To be sure, this reasoning assumes that arbitrators are competent to apply mandatory laws. Although the Supreme Court lias expressed some skepticism about the abilities of arbitrators, see Commonwealth Coatings Corp. v. Continental Cas. Co., 393 U.S. 145, 149 (1968) (recognizing the need for arbitrators to disclose any dealing that might create an impression of possible bias); Prima Paint Corp. v. Flood \& Conklin Mfg. Co., 388 U.S. 395, 407 (1967) (Black, J.. dissenting) (asserting that noulawyer arbitrators are "wholly unqualified to decide legal issues"): Wilko v. Swan, 346 U.S. 427,436 (1953) (implying that arbitrators' analysis of statutory requirements nay be less precise than desired), the extent to which arbitrators are permitted to interpret these laws under the current regimie suggests that courts and legislators are satisfied that arbitrators can indeed apply these laws correctly. 
ance. As private actors, arbitrators perform their function for private gain. Whether the private reward they seek is solely financial or a combination of financial compensation, prestige, and influence over events is immaterial. The analysis presented here requires only that the objectives of the arbitrator be furthered by an increase in the number of cases she handles.

Assuming that arbitrators seek to increase the number of arbitral panels on which they sit and that arbitration associations seek to attract business, arbitrators and arbitration associations will seek to develop reputations for providing the type of arbitration services that their potential chents want. When arbitrators are faced with a choice between applying mandatory rules and ignoring those rules in favor of the arbitration agreement, reputational concerns will cause arbitrators to favor the latter because an arbitrator who is able to establish a reputation for honoring the arbitration agreement will be more appealing to the parties.

To understand the role of an arbitrator's reputation for enforcing the terms of an arbitration agreenent, it is important to understand the process by which arbitrators are appoimted. As a general matter, the manner in which arbitrators are appointed is within the control of the parties. The agreement to arbitrate can specify almost any procedure. The most popular method for appointing arbitrators to an arbitral panel in international disputes is for each side to appoint one arbitrator, with a third arbitrator appointed either by the two selected arbitrators or by the arbitration association (or another appointing authority). The arbitration association also selects the third member of the panel in the event that the two chosen ineinbers cannot agree on a selection..$^{101}$ If the arbitration is to be conducted by a single arbitrator rather than by a panel, either the parties agree on the arbitrator, or the association (or the appointing authority) selects the arbitrator. Virtually all schemes for appointment of arbitrators specify the appointınent procedures in the arbitration agreement. As is true of other aspects of the transaction, these procedures will be chosen at the time of contracting, and the parties will seek to minimize their costs. Therefore, if a inandatory rule is costly to the parties, they will structure the procedures for the selection of arbitrators such that their

101. See International Chamber of Commerce, Rules of Arbitration art. 8(4); UNCITRAL Arbitration Rules art. 7(3); International Arbitration Rules of the American Arbitration Association art. 6(3). But see London Court of International Arbitration art. 5.5 ("The LCIA Court alone is empowered to appoint arbitrators."). 
attempt to avoid a mandatory rule succeeds. They will choose a procedure designed to yield an arbitrator or arbitral panel with a reputation for enforcing the terms of an arbitration agreement, even when this involves overlooking mandatory laws.

Cousider the above procedure for selecting arbitrators, in which each party selects one arbitrator and the two chosen arbitrators agree upon a third. If the two cannot agree upon a third, the appointing authority selects the third arbitrator. If the parties choose this mechamism for the selection of arbitrators, they will also have to choose an appoimting authority. When making the choice of appointing authority, the parties can ensure that their wish to avoid the mandatory rule will be respected simply by specifying an appointing authority with a reputation for selecting arbitrators who enforce the arbitration agreement according to its terms. To see why this is so, return again to our example. ${ }^{102}$

Example. Imagine that an issuer sells securities to an investor in an international securities offering. The parties agree upon and sign an arbitration agreement under which section 10(b) of the Securities Exchange Act and SEC Rule 10b-5 would not apply to the transaction, despite the fact that they are mandatory U.S. laws. The agreement also specifies the arbitration association that is to handle the arbitration and act as appointing authority. Suppose that after the transaction has taken place a dispute arises in which the investor argues that the issuer engaged in fraudulent representations and makes claims under Rule 10b-5. The issuer hopes that the arbitrator will ignore Rule 10b-5-a mandatory rule under the securities laws - while the investor hopes the rule will be applied. The arbitral panel is to be made up of one arbitrator selected by each party and a third selected by the two chosen arbitrators or, if they cannot agree, by the arbitration association.

Suppose that at the time they sign the arbitration agreement the parties have a choice between two arbitration associations, A and B. Arbitration association $A$ has a reputation for enforcing mandatory laws when they apply to a transaction. Association B, on the other hand, has a reputation for strictly enforcing the arbitration agreement, even when doing so is contrary to a inandatory law. If the parties choose association $A$, then the investor can ensure that the antifraud rules are applied by selecting an arbitrator who not only will apply inandatory rules, but will accept only those proposed third

102. See supra Part II.A. 
arbitrators known to apply mandatory rules. Because a failure by the arbitrators appointed by the parties to agree on a third causes association $\mathrm{A}$ to appoimt the third, and because association $\mathrm{A}$ has a reputation for appointing arbitrators that enforce inandatory laws, the investor is confident that two of the three arbitrators will enforce the antitrust rules. ${ }^{103}$ If, on the other hand, association B is selected, it is the issuer who has the advantage. By appointing an arbitrator who is prepared to enforce the arbitration agreement rather than the antifraud rules and who demands that the third arbitrator do the same, the issuer ensures that the mandatory rule will not be applied.

Now, consider which association the parties will clioose. Recall that, at the time the arbitration agreement is signed, both parties want to waive the application of the antifraud rules. The investor wants to be able to make a binding commitunent in order to make the waiver credible. A credible waiver will induce the issuer to offer compensation that exceeds the value the investor places on the antifraud rules. The issuer will refuse to offer any compensation for a noncredible waiver. If association $\mathrm{A}$ is closen, the commitinent to waive the antifraud rules is not credible because, as we have seen, the investor can ensure that the antifraud rules will be applied should a dispute arise. If, on the other hand, association $B$ is chosen, the waiver is credible because the issuer can ensure that the arbitral tribunal ignores the mandatory antifraud rules. In order to make the waiver credible, therefore, the parties will select arbitration association B.

As this example demonstrates, although the parties' selection of arbitrators will be made after the dispute has arisen, that selection will be made in the shadow of the appointing authority. By choosing an appoimting authority with a reputation for enforcing arbitration agreements according to their terms, the parties make the waiver of mandatory rules credible. Of course, arbitration associations understand the imcentives facing the parties. In order to attract busmess, they will seek a reputation for enforcing arbitration agreements, even when this means ignoring mandatory national laws. In order to develop such a reputation, arbitration associations will seek out individual arbitrators who are prepared to ignore mandatory laws. They will also adopt rules that favor the apphication of rules chosen by the par-

103. Furthermore, even the party that would prefer to have the mandatory rules applied has hittle reason to seek out an arbitrator who will apply those rules, because the battle over mandatory rules has already been lost. 
ties rather than mandatory laws. The above forces will, in turn, give individual arbitrators a strong incentive to ignore inandatory laws, because domg so makes them more attractive to arbitration associations.

The theoretical discussion above demonstrates that arbitrators have a strong incentive to apply the law chosen by the parties in the arbitration agreement rather than that required by national law. The available evidence on arbitrator behavior, although largely anecdotal, provides support for this theoretical claim. ${ }^{104}$

In one survey, albeit somewhat dated, $90 \%$ of the arbitrators surveyed felt that "they were free to ignore these rules [of substantive law] whenever they thought that inore just decisions would be reached by doing so." ${ }^{105}$ More modern discussions of labor arbitration similarly conclude that arbitrators believe they should adhere to the collective bargaining agreement rather than the law. ${ }^{106}$ Even judges have recognized that arbitrators are willing to ignore substantive legal rules. For exainple, in the securities case Wilko v. Swan, ${ }^{107}$ the Second Circuit stated that "arbitrators do not ordinarily consider themselves bound to decide strictly according to legal rules."108 Although the above evidence is from surveys of domestic, rather than international, arbitrators, there is no reason to think that the latter are more likely to apply mandatory laws than are the former. In fact, one would expect exactly the opposite. Because international transactions imphcate the laws of many countries, it is often argued that choice-of-law clauses should be more readily approved for these transactions than for their domestic counterparts. ${ }^{109}$ In the international context, arbi-

104. For a more detailed discussion of this pomt, see Ware, supra note 7, at 719-25 (collecting empirical evidence that arbitrators feel free to ignore the law).

105. Soia Mentschikoff, Commercial Arbitration, 61 ColuM. L. REV. 846, 861 (1961).

106. See JoHn S. MURRAY ET AL., PROCESSES OF DiSPUTE RESOlUTION 636 (2d ed. 1996).

107. 201 F.2d 439 (2d Cir.), rev'd, 346 U.S. 427 (1953).

108. See id. at 444; see also Barrentine v. Arkansas-Best Freight Sys., Inc., 450 U.S. 728, 744 (1981) ("Because the arbitrator is required to enforce the intent of the parties, rather than to effectuate the statute, he may issue a ruling that is mimical to the public policies underlying the [Fair Labor Standards Act], thus depriving an employee of protected statutory rights."); Alexander v. Gardner-Denver Co., 415 U.S. 36, 56 (1974) ("[T]he special role of the arbitrator . . is to enforce the imtent of the parties rather than the requirements of enacted legislation.").

109. See Scherk v. Alberto Culver Co., 417 U.S. 506, 515-17 (1974) (recognizing that the conflicts-of-law problems that will almost inevitably exist in international agreements weigh in favor of supporting contractual provisions specifying in advance the forum and apphicable law); Roby v. Corporation of Lloyd's, 996 F.2d 1353, 1363 (2d Cir. 1993) ("Forum selection and choice-of-law clauses eliminate uncertainty in international commerce and insure that the parties are not unexpectedly subjected to hostile forums and laws."). 
trators may be even more prepared to ignore mandatory laws in order to apply the law selected by the parties. ${ }^{110}$

\section{The Impact of Judicial Review}

Up to this poimt, the discussion has assumed that judicial review plays no role in the arbitral process. The preceding sections have shown that, without judicial intervention, both the parties to the transaction and the arbitrator have an incentive to ignore mandatory rules. This section considers the impact of judicial review on the parties, concludimg that it fails to change the incentives of either the parties to the transaction or the arbitrators. Judicial support for arbitration and deference to arbitral rulings rely on a presumption that arbitrators will apply the same substantive law as would domestic courts. ${ }^{111}$ As shown in Section II.B, however, this presumption is misplaced because arbitrators have an imcentive to favor the arbitration agreement over mandatory laws. Therefore, if the legal system is to prevent arbitrator misconduct, it must momitor the behavior of arbitrators in some way. Failure to provide sufficient monitoring will cause many supposedly mandatory rules to become default rules.

Under existing U.S. law, courts have two opportunities to exercise jurisdiction over a case that purports to be governed by an arbitration clause. The first of these occurs if one of the parties claims that the case should be decided by a court rather than an arbitral tribunal. That is, one of the parties may imitiate judicial proceedings before the arbitration takes place. At that time, the court nray conclude that arbitration is inappropriate under the circumstances and nuay take jurisdiction over the case rather than compel arbitration. ${ }^{112}$ The

110. See ANDREAS F. LOWENFELD, INTERNATIONAL LITIGATION AND ARBITRATION 338 (1993):

If the [arbitration] agreement contains a choice-of-law clause, it is virtually always followed. For one thing, international arbitration is part of the tradition of party autonomy that includes the freedom to choose a forum and to choose the law to govern their relations; for another, arbitrators owe their jurisdiction to the agreement of the parties, and the choice-of-law clause is a condition of that agreement.

111. See Mitsubishi Motors Corp. v. Soler Chrysler-Plymouth, Inc., 473 U.S. 614, 636 (1985) ([T]he [arbitral] tribunal ... should be bound to decide [disputes] in accord with the national law giving rise to the claim[s]"); see also Lowenfeld, supra note 3, at 1 ("Honest arbitrators do not manifestly disregard the law.").

112. Under the New York Convention and the FAA, however, courts are to force arbitration upon parties that have contracted for it and who are involved in an arbitrable dispute. See New York Convention, supra note 14, art. II, 21 U.S.T. at 2519, 330 U.N.T.S. at 38, 40; 9 U.S.C. $\S 2$ (1994). 
second opportunity to exercise jurisdiction over the case occurs when the winner seeks to enforce the arbitral ruling. At that point, the court may consider whether the arbitrator complied with the arbitration agreement and whether lie applied the relevant mandatory laws-even if the parties agreed ex ante that such laws should not apply. These two mechamisms for ensuring that arbitrators apply mandatory laws-challenges to the arbitration agreement and challenges to enforcement-leave the court with several possible approaclies to the arbitrability and enforceability questions. Unfortunately, none of the options currently available to the courts resolves the problem of mandatory rules and arbitration. This part discusses the possible approaches.

1. Demanding Evidence That the Arbitrator Will Apply U.S. Law. The court could refuse to enforce an arbitration agreement absent some assurance that the arbitrator will apply U.S. law. The party seeking arbitration might, for example, satisfy the court by pointing to language in the arbitration agreement that instructs arbitrators to apply mandatory U.S. law to the dispute. If the party seeking arbitration camot make a showing of this sort, the court would refuse to compel arbitration and would take jurisdiction over the case. Imagine, for example, an international dispute in which the laws of both the Umited States and Great Britain might plausibly apply. Suppose that there is at least one mandatory U.S. law that would be applied by a U.S. court but that would not be applied by a Britisli court. Suppose further that the arbitration agreement states that the laws of Great Britam are to apply to all disputes. Absent soine showing that the arbitrator would apply the U.S. law, contrary to the stated wislies of the parties, a U.S. court would take jurisdiction over the case.

The principal advantage of this approacl is that it ensures that mandatory laws are applied. Along witl this benefit come several drawbacks. First, the strategy undermines the benefits of arbitration. In the specific case, of course, the advantages of arbitration are lost because the parties are forced to litigate before a court. More importantly, lowever, requiring evidence that the arbitrator will apply mandatory laws frustrates many of the benefits of arbitration for all parties - even those that never find themselves in a dispute. If the availability of arbitration is conditioned on a showing that the arbitrator will apply mandatory laws, few arbitration agreements can be relied upon. Regardless of the content of the agreement, there is a risk 
that a dispute will imphicate a maudatory law-either because such a law is in genuine dispute, or because one party has constructed a claim under a mandatory law in order to gain access to the courtsand, as a result, that the arbitration clause will not be enforced. In this environment, the expected benefits of an arbitration agreenent are dramatically reduced, both because fewer cases are arbitrated aud because there is a lack of certainty regarding the forum that will hear the dispute. The benefit of certainty and clarity, emphasized by the Scherk Court, ${ }^{113}$ is lost.

A second problem with this restrictive approach to arbitration is that it is overinclusive. Because the intentions of an arbitrator cannot easily be verified by a court, courts might often refuse to enforce arbitration agreements despite the fact that the arbitrator intends to apply the mandatory rule. Thus, even cases that do not pose a problem for the enforcement of inandatory rules will be denied the benefits of arbitration.

Third, this strategy demands that courts (and hitigauts arguing before courts) anticipate the full range of issues that will come up in a given case. Because the question of arbitrability is a preliminary one, it often will be difficult for anybody to know all the relevant issues that may be imphicated in the case. In order to make eveu a mildly inforined guess about the range of issues at stake, a court must carry out a detailed examination of the issues. This is especially true when one party claims that a mandatory rule is implicated and the other party argues that the rule is not relevant to the dispute. In circumstances of this sort, the court must do much more than sinply make a prehminary ruling -it must assess the validity of claims implicating inandatory laws. Such an imquiry, of course, takes court time and is costly for the parties. Even if the court eventually refers the parties to arbitration, nierely getting the court to enforce the arbitration agreement is difficult and costly enough to make arbitration less appealing.

Finally, demanding evidence that arbitrators will apply mandatory laws is contrary to domestic statutory and case law, and would conpromise international commitments of the United States. A court refusing to enforce an arbitration agreement must ignore the policies behind both the FAA and the New York Convention, both of which favor enforcement of arbitration agreements. ${ }^{114}$ In addition, the court

113. See infra note 115 .

114. See supra note 112; Scherk, 417 U.S. 506, 520 (1974) ("The principal purpose of [the New York Convention] was to encourage the recognition and enforcement of commercial arbi- 
must ignore the view of the Supreme Court, as stated in a variety of cases, that arbitration should be encouraged-especially in international transactions. ${ }^{115}$

2. Reviewing Arbitrators' Rulings. If courts do not demand assurances regarding the application of mandatory rules when they enforce the arbitration agreement, they can revisit the case after the arbitration is completed and one party seeks to enforce the ruling. Addressing the application of mandatory laws after the arbitrator has issued a decision makes it easier to determine whether the mandatory rules were applied.

If courts are to review arbitral rulings on the question of whether a mandatory law has been applied, they must determine the standard of review. United States courts, following Mitsubishi, currently apply a standard of review that is quite deferential; many commentators, however, support a higher standard of review. ${ }^{116}$ The Article now turns to consider the two polar cases of de novo review and highly deferential review, demonstrating that both are problematic.

a. De novo review. If the court reviews the arbitral award de novo, an arbitrator's ruling that is contrary to a mandatory rule will be overruled. ${ }^{117}$ The most significant problem with de novo review is the risk of bias. It is generally accepted that one of the important advantages of arbitration in international transactions is the ability to avoid national courts that are perceived to be biased in favor of local parties. ${ }^{118}$ De novo review exposes foreign parties to this bias, undermining the perceived fairness of the process.

Another problem with de novo review is that it is inconsistent with existing U.S. law and international obhigations. As previously

tration agreements in international contracts and to unify the standards by which agreements to arbitrate are observed and arbitral awards are enforced in signatory countries.").

115. See, e.g., Scherk, 417 U.S. at 516 ("A contractual provision specifying in advance the forum in which disputes shall be litigated ... is, therefore, an almost indispensable precondition to achievement of the orderliness and predictability essential to any international business transaction."); The Bremen v. Zapata Off-Shore Co., 407 U.S. 1, 15 (1972) ("[I]n the light of present-day commercial realities and expanding international trade we conclude that the forum clause should control absent a strong showing that it should be set aside.").

116. See Ware, supra note 7, at 738 n.149 (collecting sources).

117. For simplicity, I assume that courts engaged in de novo review are always able to identify arbitral misconduct accurately. Without this assumption, the results of the analysis would be stronger than those presented.

118. See Guzman, Capital Market Regulation, supra note 5, at 634. 
discussed, the FAA provides only very limited grounds on which courts may vacate or modify an arbitral award. ${ }^{119}$ None of the permissible grounds for court intervention permits the routime de novo review of arbitral awards. ${ }^{120}$ Furthermore, requiring de novo review may represent a breach of U.S. obhigations under the New York Convention. Like the FAA, the Convention provides for only very limited review of arbitral awards. ${ }^{121}$ It might be argued that de novo review is permissible under the public policy exception to the Convention, ${ }^{122}$ but interpretmg the public policy exception in this way is contrary to current U.S. and international practice. In the United States, for example, courts have reviewed arbitral awards quite deferentially, typically looking only to the question of whether certain basic forms of procedural fairness were present. ${ }^{123}$ In any event, as the Mitsubishi Court recognized, such a broad interpretation of the public policy exception would undermine the fundanental objectives of the New York Convention by greatly increasing the cost of enforcing arbitral awards. ${ }^{124}$

A common objection to de novo review of arbitral awards is that it undermines the predictability and cost savings that arbitration provides. ${ }^{125} \mathrm{~A}$ de novo standard leads to a detailed inquiry that is costly for the parties. De novo review, then, presents the danger that arbi-

119. See supra notes 32-37 and accompanying text.

120. Other commentators also have made this point. See Stephen L. Hayford, Law in Disarray: Judicial Standards for Vacatur of Commercial Arbitration Awards, 30 GA. L. REv. 731, 814 (1996) (asserting that a standard allowing a court to review the merits of an arbitral award "is not legitimate" and is "inconsistent with the public policy underlying section 10(a) of the FAA"); Ware, supra note 7, at 737 ("Imposing de novo judicial review, as opposed to allowing parties to contract into it by requiring the arbitrator to apply the law, may be difficult to reconcile with the FAA."). But see EDWARD BRUNET \& ChARLES B. CRAVER, AlTernative DISPUTE RESOLUTION: THE ADVOCATE'S PERSPECTIVE 411-12 (1997) (arguing that courts do, indeed, have the authority to vacate awards when the arbitrator has failed to apply a mandatory rule).

121. See supra note 38 and accompanying text.

122. See New York Convention, supra note 17, art. V(2)(b), 21 U.S.T. at 2520,330 U.N.T.S. at 42 (stating that "[r]ecognition and enforcement of an arbitral award may ... be refused" if "[t]he recogmition or enforcement of the award would be contrary to the public policy of [the particular jurisdiction]").

123. See Park, supra note 7, at 644-45 (outlining the grounds upon which a court may refuse to enforce an arbitral award).

124. See Mitsubishi Motors Corp. v. Soler Chrysler-Plynnouth, Inc., 473 U.S. 614, 638 (1985) ([T]he efficacy of the arbitral process requires that substantive review at the award-enforcement stage remaim minimal").

125. See Becker, supra note 83 , at 447 ; Park, supra note 7, at 642 ; Posner, supra note 7 , at 651. 
tration will represent little more than a costly precursor to trial. The arbitration itself serves no significant purpose because it is the court's ruling that ultimately resolves the case. According to this critique, arbitration simply serves to increase the costs of dispute resolution because it imposes one more level of hitigation.

Contrary to the above concern, however, de novo review need not lead to the costly litigation of each case. If it is known that courts are prepared to review arbitral decisions de novo, this knowledge will affect the behavior of the parties and the arbitrator. An arbitration clause that seeks to avoid a mandatory law might be enforced by an arbitrator, but both parties would know that such a clause would subsequently be litigated before a court-where the mandatory rule would be applied. Ultimately, the mandatory law applies, suggesting that a contrary choice-of-law provision is not credible. As discussed earher, ${ }^{126}$ if the waiver of substantive rights is not credible, it carries no value. Thus, if arbitration decisions are reviewed de novo, parties will not seek to avoid mandatory rules, and arbitrators will apply those rules.

For reasons discussed in more detail in Section III.D.1, a regime in which arbitrators apply mandatory rules will greatly reduce the number of cases brought before courts for review. Although individual cases that go through arbitration only to be reviewed de novo by a court will lose the benefits of arbitration, the large majority of cases will not be brought to a court and, therefore, will enjoy the cost savings and certainty of arbitration.

b. Deferential review. If de novo review is unsatisfactory, courts can engage in deferential review of arbitral decisions-as they do under existing law. ${ }^{127}$ Such review obliges courts to enforce arbitral awards absent compelling evidence that the arbitrator ignored mandatory rules. Although this approach reduces the costs of review for both the court system and the parties, it fails to provide sufficient supervision of arbitral rulings and, therefore, fails to ensure the application of inandatory rules.

As an initial matter, note that deferential review is necessarily underinclusive. In only a small percentage of the cases in which an arbitrator has ignored mandatory rules will that action be sufficiently

126. See supra notes $91-92$ and accompanying text.

127. See Tom Cullinan, Contracting for an Expanded Scope of Judicial Review in Arbitration Agreements, 51 VAND. L. REV. 395, 397-98 (1998). 
evideut for a court to refuse enforcement of the award. Because the court is able to observe only the final decision of the arbitrator and whatever written opmion the arbitrator provides, it is extremely difficult, in all but the simplest cases, to determine whether a particular mandatory law was applied by the arbitrator. In some cases, arbitral rulings are issued without any reasoned opinion, makmg it even more difficult for a court to conclude, upon a preliminary imspection, that the arbitrator ignored mandatory rules. ${ }^{128}$ Indeed, in the United States, the practice of issumg an award without a reasoned opinion is often adopted specifically to avoid giving the loser any grounds upon which to challenge tlie award. ${ }^{129}$

From the perspective of the parties, the fact that only a fraction of arbitral awards ignoring mandatory rules will be refused enforcement by the courts makes it possible to opt out of virtually any mandatory rule-as long as the parties can find an arbitrator willing to ignore those rules and the arbitrator's failure to follow the rules is not obvious. ${ }^{130}$ Deference to arbitrators, therefore, fails to prevent arbitration from converting mandatory rules into default rules. ${ }^{131}$ Although attempts to avoid mandatory rules will sometimes be frustrated, this will happen only occasioually. Knowing that in nrauy cases the arbitral ruling will be upheld, parties that wish to avoid mandatory rules will still have an incentive to liave those rules ignored im arbitration, and arbitrators will be eager to follow the wishes of the parties, as discussed im Part II. It is true that the risk of a court's refusing to enforce

128. Written decisions, however, are more common in the international setting than in the doinestic setting. See BRUNET \& CRAVER, supra note 120, at 324 ("Only in a few, specialized types of arbitrations do arbitrators routinely craft written decisions-labor arbitrations, international commercial arbitrations, and maritime arbitrations."); 1 IAN R. MACNEIL ET AL., FEDERAL ARBITRATION LAW \$ 3.2.3, at 3:13 (1994) (noting that arbitrators generally do not write opinions); 3 id. $\$ 37.4 .1$, at $37: 10$ (noting that arbitrators have no obhgation under the FAA "to make findings of fact or conclusions of law, or otherwise to give reasons for their awards" (footnotes oinitted)).

129. The then-president of the American Arbitration Association wrote that reasoned awards are "dangerous because they identify targets for the losing party to attack." $R$. COULSON, BUSINESS ARBITRATION: WHAT YOU NEED TO KNOW 25 (2d ed. 1982); see also Stephen L. Hayford, A New Paradigm for Commercial Arbitration: Rethinking the Relationship Between Reasoned Awards and Judicial Standards for Vacatur, 66 GEO. WASH. L. REV. 443, 446-47 (1998) (noting that reasoned awards would imcrease the likelihood of court challenges to awards and would also "increas[e] the formahty, the cost, and the time to decision in commercial arbitration").

130. Recall that arbitrators have an incentive to enforce arbitration agreements, even if they are contrary to mandatory rules. Finding an arbitrator willing to ignore mandatory rules, therefore, is unlikely to be difficult.

131. For a detailed discussion of this point, see Ware, supra note 7, at 719-25. 
an arbitral award increases the cost of attempting to avoid mandatory rules. Rather than bear this cost, some parties may choose to accept the application of mandatory rules to their disputes. There is, however, no reason to expect this to affect more than a small number of marginal transactions. To influence more transactions, courts would have to conduct a more thorough review and identify a larger share of those who attempt to avoid mandatory rules. Increasing the level of review, of course, mtroduces the problems of de novo review discussed above. For most transactions, therefore, the possibility of review is unlikely to affect the parties' choice of arbitration over a court system or their preference for avoiding the mandatory law.

Turning to the effect on an arbitrator of a court's refusal to enforce an award, it is unlikely that the mere risk of reversal can correct the arbitrator's imcentives. It is true that a reversal may have some impact on an arbitrator's reputation, but the reputational effect will not necessarily lead to greater respect for mandatory rules. ${ }^{132}$ Reversal by a court will have two effects on an arbitrator's reputation. First, an arbitrator who is reversed may be seen as one who cannot successfully "fool" a court into beheving that the inandatory rules were applied when, in fact, they were not. That is, the arbitrator may be seen as someone who is unable to meet the needs of the parties to the transaction because he lacks certain skills-in particular, the ability to deceive a court. ${ }^{133}$ This reputational effect is bad for the arbitrator, but only $\mathrm{m}$ the sense that the parties to a transaction will look for an arbitrator who can more consistently ignore mandatory rules without bemg reversed. Rather than mcrease the likelihood that an arbitrator will apply mandatory rules, this reputational effect will simply increase the competition among arbitrators willing to ignore mandatory rules and increase the payoff to those arbitrators who are most adept at misleading courts.

Second, a reversal may simply indicate that the arbitrator is willing to overlook mandatory rules when that is the will of the parties, as expressed in their arbitration agreement. Even the most skilled arbitrators, when they ignore mandatory rules, will occasionally be reversed by the courts. That a particular arbitrator is reversed, therefore, may signal that she is willing to ignore mandatory rules. From this perspective, reversal is a sign that an arbitrator is desirable.

132. See Posner, supra note 7, at 651 .

133. See id. at 655-56. 
Neither of the reputational effects of a court's refusal to enforce an award, therefore, is likely to lead to an increase in the frequency with which arbitrators apply inandatory rules that the parties seek to avoid. The problem with judicial review is that it fails to address directly the problein of arbitrators' incentives. A court's refusal to enforce an award does not inpose a direct cost on arbitrators who ignore mandatory rules and, therefore, fails to influence the incentives of arbitrators. As long as the parties have an ex ante desire to avoid mandatory rules, arbitrators will try to accommodate those desires unless they face some offsetting cost when they do so. Although it is true that arbitrators who ignore inandatory rules may be reversed, and that those who are bad at hiding their inotives froin courts will be reversed more often, both the parties to the transaction and the arbitrators will still have an incentive to ignore inandatory rules.

If the risk of judicial review successfully aligned the arbitrator's incentives with those of the legal system, the problem of inandatory rules in arbitration would be solved. In his recent article, Professor Eric Posner argues that the Mitsubishi Court sought to address the incentives of arbitrators. ${ }^{134}$ Posner presents a model in which courts choose to enforce arbitral awards in soine cases and to review them in others. ${ }^{135}$ The choice between enforcing and reviewing is random. Posner argues that in his model this strategy is optimal because it induces arbitrators to respect mandatory rules in at least some cases. ${ }^{136}$ Assuming that Posner's model is correct, and assuming that his mixed strategy equilibrium is the correct one ${ }^{137}$ a mixed strategy outcome remains less desirable than one in which mandatory rules are followed as a nnatter of course by arbitrators. Thus, even if Posner's defense of Mitsubishi represents an accurate positive account, one would prefer, as a normative matter, a different outcome. Part III demonstrates that arbitrator hability introduces incentives that lead to an equilibrium in which arbitrators respect mandatory rules in every case.

134. See id.

135. See id. at $654-68$ (describing the model).

136. See id. at 668 .

137. Posner accurately points out that there are at least three possible equilibria in his inodel. In the first, the "pure arbitration equilibrium," arbitrators ignore mandatory rules and courts enforce those rules. See id. at $658-60$. In the second, the "no arbitration equilibrium," courts try cases de novo, and parties do not use arbitration clauses. See id. In the third, the "partial arbitration equilibrium," both courts and arbitrators adopt mixed strategies. See id. at $660-$ 61. 


\section{REALIGNING INCENTIVES}

\section{A. Arbitrator Liability}

The role of an arbitrator is often analogized to that of a judge. ${ }^{133}$ Once we have this analogy in mind, we naturally view judicial review of arbitral decisions as analogous to review of judicial decisions. Despite its superficial similarity to a court action, however, an arbitration proceeding is more properly viewed as the product of contract. The parties to a transaction contract to arbitrate their disputes, and the arbitrator-either at the time of contracting or, more likely, after a dispute arises-contracts with these parties to resolve their dispute.

The contract between the parties and the arbitrator contains terms-both exphcit and imphcit-that are negotiated by the parties, but it also mcludes certain mandatory terms. For example, all contractual agreements imclude the obhigation to perform in good faith. ${ }^{133}$ This duty exists even if it is not specified in the contract, and it carmot be waived ${ }^{140}$ Failure to perform in good faith constitutes a breach of the contract. ${ }^{141}$

The use of arbitration can be reconciled with the presence of nandatory rules by recognizing that the arbitrator and the parties to the transaction are bound by contract and by imposing on the arbitrator a duty to apply mandatory laws in the performance of his contractual obhigations. Under arbitrator hability, the arbitrator is required to carry out his responsibilities subject to the requirement that he respect inandatory rules, just as he must carry them out subject to a duty of good faith. Like the duty of good faith, the duty to enforce mandatory rules cannot be waived by contract. Failure to apply a mandatory law constitutes a breach of contract and gives the mjured party-here, the party that would benefit from application of the mandatory law-the right to sue the arbitrator for that breach. Thus, a party to an arbitration could file suit against an arbitrator for breach of contract if the former beheved that the latter had ignored a mandatory rule and thereby failed to carry out her obhgations under the

138. See, e.g., Ware, supra note 7, at 707-08.

139. See, e.g., U.C.C. $\$ 1-203$ (1999) ("Every contract or duty within this Act imposes an obligation of good faith im its performance or enforcement.").

140. See id. $\$ 1-102(3)$ ("[O]bligations of good faith, diligence, reasonableness and care prescribed by this Act may not be disclaimed by agreement ....").

141. See id. § 1-203. 
contract. This suit would be before a court. ${ }^{142}$ If the court determined that the arbitrator had failed to apply a mandatory rule, the aggrieved party would be entitled to damages.

Notice how this proposal alters the structure of incentives. The arbitrator now faces potential hability for his failure to apply a mandatory law. As shown below, arbitrator hability encourages the arbitrator to apply the mandatory rule in the first place and thereby avoids the problems associated with the status quo. If damages are set appropriately, ${ }^{143}$ arbitrators' current imcentive to ignore mandatory rules is replaced by an incentive to apply those rules. ${ }^{144}$

Arbitrator hability also mitigates concerns of judicial bias. If courts are called upon to resolve disputes between parties, there is a risk that they will systematically favor their own citizens. Under arbitrator hability, the court is faced with a dispute between one of the parties and the arbitrator. This reduces the risk of bias in several ways. First, it may be that neither the arbitrator nor the plaintiff is a local resident or citizen. Suppose, for example, that one of the parties to a transaction is a U.S. resident while the other is not. The two parties enter into a dispute that goes to arbitration. If a U.S. court reviews the award, the non-U.S. party may be concerned that the court will be biased. Under arbitrator hability, on the other hand, the court will have an opportunity to exercise its purported bias only if the American party is still involved. If, for example, the U.S. party wins at the arbitration stage, she will not be directly involved in the suit between the arbitrator and the other party, and there is no risk of bias.

142. It is conceivable that the parties to the transaction and the arbitrator may want to provide for arbitration of any issues regarding arbitrator liability. There seems to be no compelling reason to forbid arbitration in this context, although demanding that such disputes be heard by a court may encourage finahity and prevent the appearance of a conflict of interest as one arbitrator sits in judgment of another's actions. In any event, this is a secondary issue that will not be discussed further in this Article.

143. The appropriate measure of damages is discussed in the remaining sections of Part III.

144. One additional point about inandatory rules bears mentioning. An arbitration agreement with a choice-of-law clause that is contrary to mandatory U.S. laws may generate problems outside the United States if those mandatory laws are apphed by an arbitrator. Under the New York Convention, a court nuay refuse to enforce an award if the arbitrator decided an issue that was not included in the arbitration agreement. See New York Convention, supra note 17, art. V(1)(c), 21 U.S.T. at 2520,330 U.N.T.S. at 42 . Thus, an arbitral award that applies U.S. mandatory laws even when they are contrary to the arbitration agreenent may not be enforceable outside the United States. Although this represents a vexing problem for arbitrators, the costs are ultimately borne by the parties, providing them with sufficient incentive to avoid the problem. Under a regime of arbitrator hability, parties can avoid this problem simply by stating in the arbitration agreement that all applicable inandatory laws are subject to arbitration. 
Admittedly, there will be some cases in which the risk of bias remains, but a large share of the potential instances of bias is eliminated.

A second reason why concerns about bias might be mitigated by arbitrator hability turns on the nature of the bias. In some contexts, the concern may not be that courts are biased in favor of local parties, but rather that they are biased against litigants of certam nationalities. ${ }^{145}$ Thus, for example, an American doing business in Jordan may fear that courts there will be biased against him, but an arbitrator from Egypt may not have that fear. Under arbitrator hability, the parties could mitigate the risk of bias by selecting an arbitrator, such as the one from Egypt, who is unlikely to be a target of bias in that forum. One can muagine a more draunatic exaunple featuring a transaction between an American and a non-American im which both sides agree on a American arbitrator. In this case, there is no reason to expect that the courts will be biased against the American arbitrator if he is sued by the U.S. party. These examples are specific illustrations of a inore general point: in many instances, it will be possible for the parties to select an arbitrator who can resolve the controversy in an unbiased fashion and who is less concerned about judicial bias than are the parties.

A third reason why bias is less of an issue under arbitrator liability is that disputes between arbitrators and plaintiffs may simply be less prone to judicial bias than cases mvolving review of arbitral awards. Arbitrators and arbitration associations are repeat players, and, therefore, they are able to develop reputations for honest dealing. When these parties appear before a national court, their reputations may cause judges to be less suspicious of thein than the judges are of foreign private parties that are litigating a claim. Furthermore, the fact that the plaimtiff chose the arbitrator may mdicate to the court that the arbitrator should be treated fairly and without bias.

\section{B. Level of Liability}

Holding arbitrators hable for a failure to apply unandatory laws corrects their incentive to ignore those rules, but only if dannages are set appropriately. The appropriate level of hability depends on two variables: the value the parties to a transaction place on avoiding a

145. Equivalently, the courts may have biases in favor of parties from certain parts of the world. For example, American courts may have a bias in favor of litigants from North America or Europe, Chilean courts may have a bias in favor of Latin American hitigants, and so on. 
mandatory rule and the probability that an arbitrator who ignores a mandatory rule will be found liable for her misconduct. ${ }^{146}$ Assume that the ability to avoid a mandatory rule is worth an amount, $X$, to the parties-meaning that avoiding the mandatory rule represents a joint savings of $\mathrm{X}$ dollars. When the parties establish their contract, they will be willing to pay up to $\mathrm{X}$ dollars to lave the arbitrator ignore the mandatory rule in the event of a dispute. If an arbitrator who cliooses to ignore a mandatory rule is always penalized for that decision, imposmg damages of $\mathrm{X}$ dollars corrects the arbitrator's imcentives.

If, instead, arbitrators who ignore mandatory rules are penalized only some of the time-with probability p-the level of hability must be adjusted to take this fact into account. In this situation, an arbitrator found to have failed to apply a mandatory rule should be required to pay an amount $\mathrm{X} / \mathrm{p}$. This amount represents the ex ante gain to the parties when the mandatory rule is ignored, inflated to account for the probability that an arbitrator who ignores such a rule will avoid detection. For example, if the parties to the transaction are willing to pay $\$ 1000$ to avoid a mandatory rule, and if the probability that an arbitrator who ignores sucl a rule will be caught is $25 \%$, then an arbitrator who is found to have ignored the rule should face $\$ 4000$ in liability.

Note how choosing the correct level of liability generates the proper incentives for the arbitrator. If liability is set at $\mathrm{X} / \mathrm{p}$, an arbitrator who plans to ignore a mandatory rule faces an expected cost of $\mathrm{X}{ }^{147}$ Assuming that the market for arbitration services is competitive, all of this cost will be passed on to the arbitrator's clients. ${ }^{148}$ Importantly, only those clients seeking to avoid a mandatory rule will have to pay this additional cost. For parties that are prepared to have mandatory laws apply to a transaction, there is no danger to the arbitrator, and the parties need not pay an additional fee. ${ }^{149}$ Parties that seek

146. Other relevant variables are discussed and incorporated in the remaining sections of Part III.

147. That is, if the arbitrator is found to be liable, she will have to pay $\mathrm{X} / \mathrm{p}$, but she will be found liable only with probability $\mathrm{p}$. The expected cost of ignoring a mandatory rule is, therefore, $X$.

148. Assuming that arbitration services is a competitive industry makes the presentation simpler, but analogous results would still loold under an assumption of an imperfectly coinpetitive inarket for arbitration services.

149. The underlying assumption here is that arbitrators are never found liable when they have applied the mandatory rule in good faith. This assumption is relaxed below. 
to contract with an arbitrator in order to avoid a mandatory rule, therefore, will have to pay an additional X dollars-the value they place on avoiding the mandatory rule. Thus, the liability imposed on the arbitrator and passed on to the parties makes the parties mdifferent between apphication or avoidance of the mandatory rule. If the rule is applied, the parties give up a benefit of $X$, but they also avoid the additional cost of $X$, which the arbitrator would demand in order to ignore the inandatory rule. ${ }^{150}$

\section{Repeated Games}

The discussion up to this poimt has been based on a one-shot game between arbitrators and the parties to a transaction. In this game, the arbitrator has no imcentive to enforce a contract in violation of inandatory laws because to do so imposes liability on the arbitrator. Appropriate damages ensure that inandatory rules are respected. It is elementary game theory that one-shot results also apply to repeated games of a finite duration. ${ }^{151}$

The analysis becoines inore complex, however, when we consider infinitely repeated games. In particular, there is a theoretical possibility that an arbitrator would develop a strong reputation for enforcing contracts even im the face of mandatory rules and that sucl a reputation would sustain an equitibrium im which parties to a contract were able to avoid mandatory rules. Given a sufficiently strong reputation, an arbitrator could deinand additional payment up front to coinpensate for the hability that she would face after the arbitration. Consider another variation on our example.

Example. Suppose that the issuer and the investor contract for the sale of securities. They also contract for the arbitration of future disputes and a waiver of the antifraud provisions of the securities laws. The arbitration clause stipulates that an arbitrator from XYZ Arbitration Association will be selected. This arbitration association has a strong reputation for enforcing the terms of contracts even when

150. It is assumed that the arbitrator can commit-through reputation-to ignore mandatory rules when the parties instruct him to do so. If this assumption is not inade, parties are even less likely to try to ignore mandatory rules because there is a risk that they will pay the arbitrator an additional amount, $\mathrm{X}$, only to have the arbitrator apply the mandatory rule. That is, the arbitrator may choose to "cheat" and to apply the inandatory rule in order to avoid hability even after charging for the risk of that liability. Results similar to those developed in the text could be generated without this assumption, the main difference being that the required level of hability would be lower.

151. See Douglas G. BaIrd et AL., Game THEORY AND THE LAW 159-65 (1994). 
they are in violation of mandatory laws. ${ }^{152} \mathrm{XYZ}$ 's fees are higher than the industry average because the association is frequently sued by parties that lose in arbitration and subsequently claim that the association failed to apply mandatory laws. Specifically, the association charges the market rate for arbitration plus an amount equal to the arbitrator's expected future liabihty. Call this second component of the arbitrator's fee $X$. The parties are willing to pay this higher fee because any liability placed on the arbitrator will be paid back to them (in expectation). ${ }^{153}$ Should there be a claim of fraud that is taken to arbitration, the arbitrator may be tempted to apply the mandatory antifraud provisions of U.S. securities laws, but, if the reputational effect is strong enough, she will prefer to enforce the contractual waiver of those provisions. Following the arbitration, the losing party can sue the arbitrator and will be awarded the amount $X$. The net result is that the arbitrator is paid the standard arbitration fee in exchange for her work and the parties succeed in waiving the mandatory rules.

As the example shows, for any fixed level of damages, there exists an equilibrium in which an arbitrator with a sufficiently strong reputation for enforcing contracts according to their terms enables the parties to avoid mandatory rules. For a variety of reasons, however, arbitrator liability makes such an equilibrium unlikely.

First, it is important to recognize that the mere existence of an equilibrium provides very httle information about which equilibria are likely. In infinitely repeated games, virtually any equilibrium is possible. ${ }^{154}$ It is hardly surprising, therefore, that we can identify an equilibrium that permits the parties to avoid inandatory laws. The more important question is whether that equilibrium can be supported under reasonable assumptions.

The equilibrium being considered requires that the discount rate of the arbitrator be low enough to prevent defection. Imagine an arbi-

152. Assume further that the reputation is completely lost if the arbitrator ever applies a mandatory law over a contrary contractual provision.

153. Obviously, there is a question of low the parties to the transaction share the costs of the arbitrator. We need not worry about this issue, however, because the parties will always structure their contract with the arbitrator to maximize the total value of their transaction. Whatever side payments are necessary between the parties will be made.

154. This is referred to as the Folk Theorem, which states that, "[i]n an infinitely repeated nperson game with finite action sets at eacl repetition, any combination of actions observed in any finite number of repetitions is the unique outcome of some subgame perfect equilibriun given." ERIC RASMUSSEN, GAMES AND INFORMATION: AN INTRODUCTION TO GAME THEORY 92 (1989). 
trator with a strong reputation for enforcing contractual provisions over mandatory rules. Suppose further that an arbitrator who "defects" by applying a mandatory law that contradicts a contractual provision suffers a complete loss of reputation; thereafter, it is always assumed that he will apply mandatory rules over contractual provisions. ${ }^{155}$ Finally, assume a discount rate of r. An arbitrator who never defects will receive a stream of payments equal to the fee of an arbitrator who ignores mandatory rules $(F)$ in every period. ${ }^{156}$ This imphies a present discounted value of $\mathrm{F}(1+\mathrm{r}) / \mathrm{r} .{ }^{157}$ Compare this to the payoff for an arbitrator who defects in the first period. Defection yields a payinent in the first period of the fee for an arbitrator who ignores mandatory rules $(F)$, plus the additional payment received by the arbitrator to account for the expected hability of an arbitrator who ignores mandatory rules $(\mathrm{X})$. In subsequent periods, the arbitrator receives payment as an arbitrator who enforces mandatory rules (L). This yields a present value of:

$$
\begin{aligned}
\mathrm{PV} & =\mathrm{F}+\mathrm{X}+\mathrm{L} /(1+\mathrm{r})+\mathrm{L}(1+\mathrm{r})^{2}+\ldots \\
& =\mathrm{F}+\mathrm{X}+\mathrm{L}(1+\mathrm{r}) / \mathrm{r}-\mathrm{L}
\end{aligned}
$$

It is possible to sustain an equilibrium in which the arbitrator ignores mandatory rules only if defection is worth less than nondefection. Comparing the payoffs from defection and nondefection shows that the equilibrium can be sustained if and only if:

$$
\mathrm{F}(1+\mathrm{r}) / \mathrm{r}>\mathrm{F}+\mathrm{X}+\mathrm{L}(1+\mathrm{r}) / \mathrm{r}-\mathrm{L}
$$

Simplifying, this implies:

$$
\mathrm{F}>\mathrm{L}+\mathrm{Xr}
$$

It is, therefore, impossible to sustam the equilibrium under consideration if the discount rate, $r$, is high, or if the value of avoiding the mandatory rule, $X$, is high.

If we add the reahistic assumption that different parties place different values on the avoidance of mandatory rules, then an equilibrium in which arbitrators ignore mandatory rules seems even more unlikely. Individual parties that do not value avoidance of the rule as

155. These assumptions are as favorable as possible to a reputational equilibrium in which mandatory rules are avoided.

156. For simplicity, it is assumed that the arbitrator handles one case in each period.

157. That is, the value of the payments is $F+F /(1+r)+F /(1+r)^{2}+\ldots=F(1+r) / r$. 
much as others will be unwilling to pay the premium demanded by arbitrators who ignore mandatory laws. That is, parties that would prefer to avoid mandatory rules but that value domg so at less than F$\mathrm{L}$ will prefer to select an arbitrator who applies mandatory rules. This generates a form of lemons problem. ${ }^{158}$ The remaining pool of transactions consists of those parties that value avoiding the mandatory rules the inost. This increases the expected damages faced by an arbitrator. An increase in expected damages drives up the difference between the fees charged by arbitrators who enforce mandatory laws (L) and those who do not $(\mathrm{F})$. This causes more parties to choose arbitrators who enforce mandatory rules, which again increases the expected dainages, which drives $L$ and $F$ still further apart, and so on. The end result is a collapse of the equilibrium in which arbitrators ignore inandatory rules.

There are additional reasons why the equilibrium under consideration is unlikely. First, the above discussion makes the extreine assumption that a single transaction can rum an arbitrator's reputation. If a more moderate assumption is inade-for exainple, suppose that it is difficult to observe perfectly when an arbitrator defects, implying that the penalty for defection will be much less severe-defection becomes more attractive aud undermines the equilibrium. Second, it may be extremely difficult to develop a reputation for ignoring mandatory rules. It inay require a long period of doing so without being fully compensated for the ensumg liability. Even with a low discount rate, it is unlikely to prove worthwhile to einbark on a strategy of developing such a reputation. Third, the equilibrium requires a large upfront outlay by the parties to the transaction. If one of the parties is hquidity-constrained-as will frequently be the case for investors in securities transactions, for example-that party may not be able to pay the arbitrator the amount necessary to cover both the fee and the payinent required to cover future liability.

If there nevertheless remains a concern about the existence of an equilibrium in which the parties coinpensate the arbitrator for potential future liability, adjusting the level of dainages could prevent such an outcome. For example, rather than imposing hability equal to the ex ante gain to the parties from avoiding the mandatory rule, liability could be set at an amount equal to that ex ante gain plus the fee received by the arbitrator. For an arbitrator who seeks to apply inanda-

158. See generally George A. Akerlof, The Market for "Lemons": Quality Uncertainty and the Market Mechanism, 84 Q.J. ECON. 488 (1970). 
tory rules, this would represent a modest increase in expected liability, assuming that courts sometimes impose sucl liability mappropriately. For arbitrators wlio ignore mandatory rules, however, liability of this sort would be crippling. Unlike the equilibrium discussed above, this relationship would not permit the arbitrator to increase her fees as compensation for future liability, because liability would be a function of those fees. Though not the optimal result, this strategy would still provide access to arbitration for most transactions in which arbitration is preferred over the court system.

Finally, it is important to note that whatever assumptions one makes about the beliavior of the parties and the arbitrator in an infimitely repeated game, the current system is mucli more likely to lead to an avoidance of mandatory rules than is arbitrator liability. Currently, an arbitrator who ignores mandatory rules faces no penalty. If there is no cost to ignoring mandatory rules, there is no reason for an arbitrator with a reputation for doing so to defect. Under arbitrator liability, the cost of ignoring mandatory rules can be substantial, making defection more attractive.

\section{Extension and Responses to Potential Objections}

1. Excessive Litigation. One potential concern regarding arbitrator liability is that it would promote too inuch litigation. If the losing party im an arbitration always has the ability to sue the arbitrator, the argnment miglit go, such suits will arise in virtually every arbitration. There are several reasons why this concern is misplaced.

First, it is well established that parties to a dispute will agree on a settlement when they liave the same information. It is only when the plaintiff is more optimistic about his chances at trial than is the defendant that the parties will fail to settle. ${ }^{159}$ This same result holds in the arbitration context. Where both the potential plaintiff and the arbitrator are able to anticipate the result of an arbitrator liability claim, they will settle, avoiding the expense of a lawsuit. In the majority of

159. The literature on litigation and settlement is well developed, and it is beyond the scope of this Article to explore all the variations on the likelihood of settlement. The most relevant articles for present purposes are John P. Gould, The Economics of Legal Conflicts, 2 J. LEGAL STUD. 279, 286 (1973); William M. Landes, An Economic Analysis of the Courts, 14 J.L. \& ECON. 61, 66 (1971); Steven Shavell, The Social Versus the Private Incentive to Bring Suit in a Costly Legal System, 11 J. LEGAL STUD. 333, 338 (1982). 
cases, the arbitrator will apply the relevant mandatory rules, and the losing party will recognize that her probability of success im a suit against the arbitrator is small. Because both parties recognize that the losing party has hittle hope of winning in court, they will settle the case for a small amount, or perhaps even nothing. If, on the other hand, the arbitrator has ignored the mandatory rule despite his imcentive to follow it, and this is verifiable, both parties will recognize that the losing party has a viable claim against the arbitrator and will, accordingly, settle for a relatively large amount. Only when the parties have divergent expectations will settlennent be difficult. ${ }^{160}$

Existing rules governing both arbitration and hitigation before courts demonstrate that a right to access the courts does not necessarily lead to a flood of litigation. For example, under existing rules, the losing party in an arbitration lias the right to seek judicial imtervention. ${ }^{101}$ This is possible eitlier through an attempt to avoid enforcement of the award or through a separate suit under relevant domestic laws. Nevertheless, the majority of arbitral awards are paid by the losing party without appeal to these judicial mecliamsins. The saine result is observed in hitigation. Only a small fraction of all parties with disputes make a court filing, and only a small percentage of those that file actually go to trial. ${ }^{162}$ The vast inajority of cases settle. The same can be expected of arbitrator liability disputes. There is no reason to think that there would be any more litigation when the available remedy is a suit against the arbitrator rather than an appeal from a court case.

Furthermore, one need not fear an avalanche of litigation because arbitrator hability would lead to a more consistent application of inandatory rules by arbitrators. Because arbitrators have no imcentive to ignore inandatory rules under arbitrator hability, they will apply those rules. When the arbitrator applies inandatory laws, a party that has lost in arbitration will also expect to lose before the courts.

160. In fact, divergent expectations are not sufficient. It is necessary that the plaintiff expect a higher judgment than does the defendant. If the defendant expects a larger judgment to be handed down by the court than does the plaintiff, there will be settlement.

161. See 9 U.S.C. $\$ \$ 10,11$ (1994).

162. See Marc Galanter, Reading the Landscape of Disputes: What We Know and Don't Know (and Think We Know) About Our Allegedly Contentious and Litigious Society, 31 UCLA L. REV. 4, 5 (1983); George L. Priest \& Benjamin Klein, The Selection of Disputes for Litigation, 13 J. LEGAL STUD. 1, 2 (1984); David M. Trubek et al., The Costs of Ordinary Litigation, 31 UCLA L. REV. 72, 89 (1983). 
There is, therefore, httle incentive to pursue further costly litigation because there is little hope that the outcome will be affected. ${ }^{163}$

2. Risk and Risk-Averse Arbitrators. Liability for failure to apply mandatory laws would expose arbitrators to risk. One risk is that the arbitrator will be held liable in particular cases in which she ignores mandatory rules. Another is that the arbitrator may, due to judicial error, be held hable even when the arbitrator applies mandatory rules in good faith.

There are two important sources of concern with respect to the risk of judicial error. The first is that arbitrators may be overly cautious im their application of mandatory laws. That is, even in cases where the mandatory rule should not apply, or wliere it sliould apply but the party seeking its application should nevertheless lose, an arbitrator may issue a decision in favor of the party seeking application of the rule in order to protect himself from suit. By applying a mandatory rule in close cases-even if the mandatory rule is not apphicable-the arbitrator insulates himself from liability. This behavior, of course, is liarmful because the rule, as applied by the arbitrator, will be stricter than the rule adopted by the relevant government. Consider the following example.

Example. Suppose that the issue before an arbitrator is the application of U.S. antitrust laws to a transaction that took place abroad. Imagine that the arbitrator must determine whether the United States has subject matter jurisdiction over the transaction. Finally, suppose that, after applying the U.S. test for subject matter jurisdiction, the arbitrator beheves in good faith that a U.S. court would not find subject matter jurisdiction on the facts of the case. Despite this view, however, the arbitrator may be concerned about potential liability if he rules that U.S. law does not apply. To protect himself from a possible suit by the party that seeks apphication of that law, he rules that U.S. antitrust laws apply. Thus, U.S. law is applied even though it would not be applied by U.S. courts.

163. In a similar vein, the decision of an arbitrator who applies mandatory laws may provide the parties with information regarding the strength of their respective positions. This additional information inay cause parties with divergent expectations to settle prior to litigation. If the arbitrator is expected to ignore the mandatory rule, his decision provides inuch less information about low a court, which will apply the inandatory rule, might rule. In this case, therefore, arbitrator habihity encourages settlement prior to judicial intervention in a way that judicial review does not. 
The above example, however, omits half the story. Just as the party that wants apphication of the mandatory rule would have a claim agamst the arbitrator if the mandatory law were not apphed, the party that sought to avoid the mandatory rule would have an equal right to pursue a claim if the arbitrator apphed a mandatory rule inappropriately. In other words, arbitrator hability would impose a duty on the arbitrator to apply mandatory rules in the same fashion as would a national court. The arbitrator could be sued for a failure to apply the law when it should be apphed or for applying it when it should not be apphed. An arbitrator, therefore, would have no reason to do anything other than attempt to apply mandatory rules in the same circumstances and in the same fashion as they would be apphed by courts in the relevant jurisdiction.

Admittedly, the arbitrator must be compensated for accepting the risk of liability. One would therefore expect the costs of arbitratiou to increase at least shightly. Once again, however, the incentives would work to ensure that arbitrators respect mandatory laws. In order to attract customers, arbitrators compete not only through the quality of their decisions and the desirability of their procedures, but also on price. An arbitrator who routinely follows mandatory rules will be able to offer her customers a lower price because she faces less chance of being held hable for the failure to apply such rules. Similarly, as between two arbitrators who seek to apply mandatory rules when appropriate, the more capable arbitrator will be able to charge a lower price because he will interpret the laws more accurately and, therefore, face fewer lawsuits.

An arbitrator is likely to take action im order to reduce the risk of liability. The actions arbitrators are most likely to take are, for the most part, good for the arbitral process and the legal system. The most obvious way for an arbitrator to protect herself from future hitigation is to follow the mandatory rule at issue and to provide a reasoned decision that explains why she apphed the rule and how the rule led to her decision. A written decision of this sort provides three important advantages for the arbitrator. First, if one of the parties sues the arbitrator, the decision will provide evidence that she followed the apphicable mandatory laws. Second, in the event of a lawsuit, the opinion represents a form of advocacy, outlining the reasoning of the arbitrator and explaining why the decision was correct. Third, if a party threatens to sue, the written decision will increase the probability that the parties will have the same expectations about how 
a court would decide the question -increasing the probability of early settlement.

The second source of concern regarding arbitrator behavior is that arbitrators are risk-averse and may demand very high compensation $\mathrm{m}$ order to accept the risk of hability. Although it is certainly true that arbitrators may be risk-averse, there are several reasons to think that they would not require excessive compensation in order to participate. ${ }^{164}$ First, many arbitrators are repeat players. An arbitrator who sits on many panels might find hinself liable froin time to time, but this risk would be spread over many cases. By clrarging a small premium for eacl case, the arbitrator could self-msure against this risk. Note also that this form of self-insurance would be inore expensive for arbitrators who ignored mandatory rules on a regular basis. Sucl arbitrators would be more likely, in any given case, to be found hable by a court and, therefore, would have to charge a higher premium to their customers. This, in turn, would give arbitrators who applied inandatory rules a price advantage.

Second, even when an individual arbitrator is risk-averse, an arbitration association is hikely to be risk-neutral. Like the repeat-player arbitrator in the previous paragraph, an arbitration association handles a large number of arbitration cases and is able to spread the risk of hability over them. If the arbitration association is risk-neutral (or even if it is less risk-averse than the arbitrator), botll it and the arbitrator will find it advantageous for the association to msure the arbitrator. This form of insurance simply represents a transfer of the risk of hability from the arbitrator to the association. A transfer of this sort is likely because the risk-neutral association can bear the risk at lower cost tlian can the risk-averse arbitrator. From a policy perspective, it miglit even be desirable to lold the association jointly liable for the failure of the arbitrator to comply witl inandatory rules. Joint liability has the additional benefits of reducing the risk that arbitrators will be damage-proof and giving the losing party in the arbitration a greater set of options in brimging a suit for failure to apply a inandatory law. It also forces the arbitration association eitlier to pool its individual arbitrators' risks or to charge ligher fees for arbitrators that ignore mandatory laws. Regardless of the approach the associa-

164. Notice that, if arbitrators are risk-averse, the risk that arbitrator liability will lead to litigation is reduced beyond what is suggested in Part III.D.1, because risk-averse parties prefer settlement to higation, making it possible for thein to settle even when risk-neutral parties would not do so. 
tion takes, it is forced to internalize the costs of liability-causing it to nonitor the behavior of its arbitrators and to adjust its fees accordingly.

Another option for arbitrators is to purchase insurance to cover their losses. An arbitrator who purchases insurance to cover her liability will still have an incentive to apply mandatory rules because the insurance company will want to monitor her behavior and adjust lier premiums to reflect the risk of hability.

In addition to the arbitrator and the association, the parties to the transaction are available to bear some of the risk of a lawsnit. Although arbitrator hability does not allow a waiver of the right to sue arbitrators, there is no reason to prevent an agreement under which the winning party in the arbitration would have to indemnify the arbitrator against hability. Indemnification simply transfers the cost of a failure to apply the niandatory rule directly to the parties.

All of the above options go to the question of who should bear the risk. If this is left to private ordering, the least risk-averse party will agree to bear the risk for an appropriate fee. This does not undermine the arbitrator liability scheme because the fee charged to bear the risk will reflect the likelihood and magnitude of liability.

3. Relaxing Informational Assumptions. The above discussion assumes that all the parties know, at all times, whether the arbitrator will apply the rule. Suppose imstead that it is not known until the dispute arises whether the arbitrator will have to cloose between the content of the arbitration agreement and a nuandatory rule. This might occur, for example, if the exact issues to be raised are not known until the arbitration begins. If, for example, the hitigation strategy of one of the parties clianges or new information becoines available during the arbitration, there nray be questions regarding the applicability of a mandatory rule that were not anticipated at the start of the case.

If prior to the start of the arbitration-at the time the parties and the arbitrator agree on a fee-there is a probability, $k$, that the arbitrator will be asked to ignore a mandatory rule, and assuming that the arbitrator plans to do so if asked, the expected liability of the arbitrator is $\mathrm{kX}$. This represents the arbitrator's expected liability for ignoring a nuandatory rule, discounted by the probability that sle will face such a rule. This is the cost that will be passed on to the parties. The ex ante benefit to the parties of having an arbitrator who will ignore niandatory rules is simply the value of avoiding the mandatory rules, 
$\mathrm{X}$, discounted by the probability that the arbitrator will have to resist apphication of those rules, $\mathrm{k}$. Thus, the parties must pay an additional $\mathrm{kX}$ to hire an arbitrator who is willing to ignore mandatory rules, and this is exactly the same as the expected benefit of hiring such an arbitrator. Once again, the parties are indifferent between having the mandatory rules applied or having thein ignored.

It is also possible to relax the assumption that arbitrators who apply inandatory rules will never be found hable. Instead, assume that an arbitrator who does so will wrongly be found hable in soine cases. The presence of these "false positives" can be accommodated simply by adjusting the level of damages. Assume furtler that an arbitrator who applies all mandatory rules in good faith will nevertheless be found liable with probability $\gamma$. The level of damages that will provide the appropriate level of deterrence is an amount, D, such that the expected hability of ignoring a mandatory rule exceeds the expected liability from applying that rule by $\mathrm{X}$, the expected benefit from ignoring the rule. Thus, the correct level of hability is given by $\mathrm{pD}-\gamma \mathrm{D}=$ $\mathrm{X}$, which can be simplified to $\mathrm{D}=\mathrm{X} /(\mathrm{p}-\gamma)$. If damages are set equal to $\mathrm{D}$, arbitrators will face the correct incentives even if courts occasionally impose liability on an arbitrator who has apphed all mandatory laws.

The above discussion establishes the level of hability, given the probability that an arbitrator who ignores mandatory rules will be found hable. That probability will be higher or lower depending on the burden of proof that is imposed on the plaintiff in such a suit. As a natter of deterrence, any burden of proof can be accommodated by adjusting the level of hability. The burden of proof merely determines $\mathrm{p}$, the probability that the court will find hable an arbitrator who has ignored a mandatory rule, and $\gamma$, the probability of false positives. As long as the level of liability, $\mathrm{X}$, is adjusted appropriately, it is possible to achieve the desired level of deterrence. ${ }^{165}$

Example. Suppose that a mandatory rule imposes on a transaction a net cost of $\$ 1000$. Assume also that an arbitrator who ignores this mandatory rule will be found hable $25 \%$ of the time and that an arbitrator who apphes the mandatory rule will be found liable $5 \%$ of the time. In order to generate the proper incentives, damages should be set at $\$ 5000$ ( $\$ 1000 /(.25-.05))$. Faced with the mandatory rule, the arbitrator can choose to ignore it, im which case he faces expected li-

165. This is a version of results developed in the famous paper by Gary S. Becker, Crime and Punishment: An Economic Approach, 76 J. POL. ECON. 169, 180-81 (1968). 
ability of $\$ 1250$. Alternatively, he can apply the mandatory rule, in which case his expected liability is $\$ 250$. Therefore, he will require that the parties pay him an additional $\$ 1000$ to ignore the mandatory rule. This amount is equal to the value that the parties place on avoiding the inandatory rule, making them indifferent between avoiding the rule or having it apply.

Finally, it is possible to relax the assumption that the parties to a transaction are able to identify, ex ante, arbitrators who are prepared to ignore mandatory rules. If it is not possible to distinguish those who apply mandatory rules from those who do not-implying that reputational mechamisms are insufficient to separate the two groupsthen arbitrator hability provides an even stronger incentive for arbitrators to follow mandatory laws. If the parties to a transaction caumot identify arbitrators who will ignore inandatory rules in favor of the arbitration agreement, the parties must use some other criteria to select arbitrators. Because arbitrators who follow mandatory rules face a lower expected level of hability, they are able to offer a lower price, making them more attractive. Assuming, once again, that the arbitration industry is competitive, the cost advantage of arbitrators who apply mandatory rules will drive those who ignore such rules out of the market. The only sustainable equilibrium in this environinent is one in which all arbitrators apply inandatory rules.

4. Verifiability. Courts charged with reviewing an arbitral decision under existing U.S. rules often inust overcome significant informational problems. A court sitting in review of an award may have difficulty determining whether a mandatory rule was apphed. Even when the arbitrators' actions are observable to the parties, it may be impossible for a court to verify that a mandatory rule was considered appropriately. This outcome is precisely what the parties to a transaction want if they wish to avoid a mandatory rule. If the parties know whether the arbitrator has followed the mandatory rule but the courts do not, the arbitrator has an incentive to follow the wishes of the parties im order to develop his reputation for doing so. By selecting an arbitrator who does not customarily issue reasoned decisions, for exaunple, an arbitration agreement can make it virtually impossible for the losing party in the arbitration to have a court reverse the decision. Because the arbitrator has an incentive to ignore the mandatory rules in order to increase his reputation as an arbitrator who gives the parties what they want, a lack of review means the parties can achieve their goal of avoiding a inandatory rule. 
Although arbitrator hability does not completely resolve the problem of verifiability, it does reduce the magnitude of the problem relative to the current system. First, as discussed above, arbitrator liability gives the arbitrator an incentive to produce a reasoned decision, whereas current law provides no sucl imcentive. ${ }^{166}$ Witl a reasoned decision, of course, it is much easier for a court to determine whether the arbitrator applied a mandatory rule to the dispute. Second, because arbitrator liability brings the arbitrator lierself before a court, slie has an opportumity to explain how sle arrived at her decision. This provides an arbitrator who considered a mandatory rule the opportunity to show that sle did so and gives the court an opportunity to assess lier credibility. By bringing the arbitrator before a court, arbitrator hability increases the likelihood that arbitral decisions will be verifiable.

5. Jurisdiction. If arbitrator liability is to lave the desired impact on the incentives of arbitrators and the parties to a transaction, not only must the substantive right to sue exist but so must the procedural ability to bring the arbitrator under the jurisdiction of the relevant national courts. Because international arbitration can take place in virtually any location, and because arbitrators may be of any nationality, a country may lack personal jurisdiction over the arbitrator. This, lowever, is unlikely to present a serious problem and, in any case, can easily be addressed.

The problem of jurisdiction is unlikely to be a serious one because the principal arbitration associations will meet the requirements of personal jurisdiction in most cases. In the United States, for example, personal jurisdiction exists over all the major arbitration associations based on their contacts with the country. Even if personal jurisdiction does not exist, it can easily be ensured by requiring that arbitrators consent to the jurisdiction of U.S. courts. The consent of a party to a contract is sufficient to establish jurisdiction over that person or entity. ${ }^{167}$ The necessary consent can be obtained by refusing to enforce arbitration agreements or arbitral awards im the absence of such consent. Sucl a policy implies that the agreement to arbitrate is

166. See supra Part III.D.2.

167. See, e.g., Insurance Corp. of Ireland v. Compagnie des Bauxites de Guinee, 456 U.S. 694, 704 (1982) (referring specifically to agreements to arbitrate); National Equip. Rental, Ltd. v. Szukhent, 375 U.S. 311, 316 (1964) ("[P]arties to a contract may agree in advance to submit to the jurisdiction of a given court ...."). 
not a credible commitment unless the arbitrator has submitted to the jurisdiction of the United States. Parties to a transaction then have an incentive to select arbitrators (or arbitration associations) that have submitted to U.S. jurisdiction; otherwise, the agreement to arbitrate can be avoided at any time simply by pursuing legal remedies im U.S. courts. Arbitrators, in turn, would have an incentive to submit to the jurisdiction of U.S. courts in order to attract business. ${ }^{168}$

Conditioning recognition and enforcennent of an arbitral award on jurisdiction over the arbitrator should be permissible under the New York Convention's public policy exception. There is no doubt that a country can refuse recognition and enforcement of an arbitral award when to do so would undermine the mandatory laws of that country. ${ }^{169}$ Requiring that arbitrators submit to local jurisdiction represents a less imtrusive and more effective mechanism to achieve the same public policy objectives.

\section{CONCLUSION}

The increased popularity and importance of arbitration in both domestic and international business make the study of arbitration and its legal regulations imperative. The acceptance and, indeed, encouragement of arbitration clauses promise significant benefits to the parties to a contract - in the form of lower costs and greater flexibilityand to the legal systein as a whole-in the form of a reduced burden on courts. If we cannot rely on arbitrators to apply the law, however, disputes that are deemed arbitrable are taken beyond the reach of legislators. Because arbitrators and arbitration associations owe their allegiance to the marketplace rather than to the state, arbitrators have an incentive to follow the wishes of the parties rather than those of lawinakers. In contracts that have no third-party effects and that are formed by consensual parties able to protect their own interests, there is reason to permit the parties to opt out of legal rules as they see fit. Where third-party effects are present, however, or where one or more of the parties is unable to protect her interests, legislators sometimes choose to regulate these transactions through the implementation of inandatory rules.

168. In a similar fashion, of course, arbitrators will have an incentive to submit to the jurisdiction of other countries that adopt arbitrator liability.

169. See supra notes $82-83$ and accompanying text. 
This Article is the first to demonstrate that the benefits of arbitration can be reconciled with the objectives of mandatory rules. A policy of arbitrator liability would align the incentives of arbitrators and the parties with those of the government. Rather than relying on heavy-handed judicial review of arbitral decisions, arbitrator hability relies on the parties themselves to exercise their private right of action if an arbitrator fails to behave appropriately. 